\title{
Observational Methods for Assessing Ergonomic Risks for Work-Related Musculoskeletal Disorders. A Scoping Review
}

Métodos observacionales para evaluar los riesgos ergonómicos de los Desórdenes Músculo esqueléticos relacionados con el trabajo: revisión del alcance

\author{
Métodos observacionais para avaliar \\ os riscos ergonômicos das Desordens \\ Musculoesqueléticas relacionados \\ com o trabalho: revisão do alcance \\ Grooten, Wilhelmus Johannes Andreas ${ }^{* 1}$; \\ Elin Johanssons, $\mathrm{PhD}^{2}$
}

Received: October 10, 2017 / Accepted: November 24, 2017

Doi: http://dx.doi.org/10.12804/revistas.urosario.edu.co/revsalud/a.6840

To cite this article: Grooten WJA, Johanssons E. Observational Methods for Assessing Ergonomic Risks for Work-Related musculoskeletal disorders. A Scoping Review. Rev Cienc Salud. 2018; 16(especial): p. 8-38. Doi: http://dx.doi.org/10.12804/revistas.

urosario.edu.co/revsalud/a.6840

\section{Abstract}

Introduction: Work-related musculoskeletal disorders (wRMSDs) are one of the most common causes of absence from work. Exposures in the work environment can cause or aggravate the impact of these musculoskeletal disorders and the identification of ergonomic exposures are essential in risk assessment. It is important to assess all three key indicators of these exposures (intensity, frequency and duration) for being able to estimate the risk level for the development of wrmsDs. Aim: This paper aims to give an overview of some of the observational methods that can be used for assessment of ergonomic risks at the workplace. Methods: This study was conducted as a scoping review of the

1 Karolinska Insitutet, Department of Neurobiology, Caring Sciences and Society, División of Physical Therapy.

* Corresponding author: Wim.Grooten@ki.se

2 University of Gävle, Faculty of Health and Occupational Studies, Department of Occupational and Public Health Sciencies; Centre for Musculoskeletal Research. E-mail: elin.johansson@ki.se 
medical and ergonomic literature and official governmental webpages in Sweden, U.S.A. and the Netherlands. Results: In total, 19 different observational methods were identified. We summarize our findings based on the body parts that were studied and what key indicators were assessed: 1) intensity of the work load (posture and force production), 2) frequency of the work load (e.g. repetitive movements), and 3) the duration of the work load (e.g. static work). In an appendix we include a brief presentation of these methods together with the work sheet (if available) and the source reference of the observational method. Conclusion: For ergonomists that perform risk assessments, there is a large number of observational assessment tools available and it is important to understand that different methods can be used simultaneously to be able to estimate the objective risk levels for wRMSDS.

Keywords: assessment, ergonomics, musculoskeletal disorders, observational methods, risk.

\section{Resumen}

Introducción: los desórdenes músculo-esqueléticos relacionados con el trabajo (DME) son una de las causas más comunes de la ausencia laboral. Las exposiciones en el entorno de trabajo pueden causar o agravar el impacto de estos desórdenes músculo-esqueléticos y la identificación de exposiciones ergonómicas es esencial en la evaluación de riesgos. Es importante evaluar los tres indicadores clave de estas exposiciones (intensidad, frecuencia y duración) para poder estimar el nivel de riesgo para el desarrollo de DmE. Objetivo: este artículo tiene como objetivo proporcionar una visión general de algunos de los métodos de observación que se pueden utilizar para evaluar los riesgos ergonómicos en el lugar de trabajo. Métodos: este estudio se realizó como una revisión del alcance de la literatura médica y ergonómica y de las páginas web gubernamentales oficiales en Suecia, EE. UU. Y los Países Bajos. Resultados: en total, se identificaron 19 métodos de observación diferentes. Resumimos nuestros hallazgos en función de las partes del cuerpo que se estudiaron y los indicadores clave evaluados: 1) la intensidad de la carga de trabajo (postura y producción de fuerza), 2) la frecuencia de la carga de trabajo (por ejemplo, movimientos repetitivos) y 3) la duración de la carga de trabajo (por ejemplo, trabajo estático). En un apéndice incluimos una breve presentación de estos métodos junto con la hoja de trabajo (si estaba disponible) y la fuente de referencia del método de observación. Conclusión: para los ergónomos que realizan evaluaciones de riesgo hay una gran cantidad de herramientas de evaluación observacional disponibles y es importante comprender que se pueden usar diferentes métodos simultáneamente para poder estimar los niveles de riesgo objetivo para DME.

Palabras clave: evaluación, ergonomía, desórdenes músculo-esqueléticos, métodos de observación, riesgo.

\section{Resumo}

Introdução: as desordens musculoesqueléticas relacionadas com o trabalho (DME) são uma das causas mais comuns da ausência do trabalho. As exposições no entorno de trabalho podem causar ou agravar o impacto destas desordens musculoesqueléticas e a identificação de exposições ergonómicas são essenciais na avaliação de riscos. É importante avaliar os três indicadores chave destas exposições (intensidade, frequência e duração) para poder estimar o nível de risco para o desenvolvimento de DME. Objetivo: este artigo tem como objetivo proporcionar uma visão geral de alguns dos métodos de observação que se podem utilizar para avaliar os riscos ergonômicos no lugar de trabalho. Métodos: este estudo se realizou como uma revisão do alcance da literatura médica e ergonômica e dos sites governamentais oficiais na Suécia, nos Estados Unidos e nos Países Baixos. Resultados: em total, identificaram-se 19 métodos de observação diferentes. Resumimos os nossos achados em função das partes do corpo que se estudaram e os indicadores chave avaliados: 1) a intensidade da carga de trabalho (postura e produção de força), 2) a frequência da carga de trabalho (por exemplo, movimentos repetitivos) e 3) a duração da carga de trabalho (por exemplo, trabalho estático). Em um anexo incluímos uma breve apresentação destes métodos junto à folha de trabalho (se estava disponível) e a fonte de referência do método de observação. Conclusão: para os ergonomistas que realizam avaliações de risco, há uma grande quantidade de ferramentas de 
avaliação observacional disponíveis e é importante compreender que podem-se usar diferentes métodos simultaneamente para poder estimar os níveis de risco objetivo para DME.

Palavras chave: qavaliação, ergonomia, desordens musculoesqueléticas, métodos de observação, risco.

\section{Background Ergonomics}

Ergonomics involves the interaction between human, technology and organization in working environment affect the individual, the company and the community. Therefore, well planned ergonomic working environment not only implies health benefits for the individual but also lead to increased quality and productivity gains for the company (2) and for society (3). A specific part within the field of ergonomics is, according to the international ergonomics association (IEA), the compatibility among human anatomical, anthropometric, physiological and biomechanical characteristics and the static and dynamic parameters of physical work (4). Relevant issues are thus working postures, materials handling, repetitive movements, static work, work-related disorders and safety and health (4), aiming to prevent the occurrence of injuries of the musculoskeletal system. These injuries are one of the most common causes of absence from work, leading to individual suffering and enormous costs for society. The most common body-parts that are affected are neck/shoulder and low back (5). Biomechanical exposures in the work environment can cause (6) or aggravate (7) the impact of these injuries, therefore the term work-related musculoskeletal disorders (wRMsDs) is often used to describe these injuries (4).

Prevention of wRMSDs is less costly than rehabilitation and preventive measures aim to detect the potentially harmful ergonomic work situations at an early stage, before wRMSDS occur (2). This process of identifying and classifying the risk levels for wRMSDs is called risk assessment. Risk assessment should be performed systematically by the employer, but there is often a need for an ergonomists with more extensive knowledge about workenvironmental conditions. Although risk assessment often is used on an individual level, for example in the investigation if the msD of a specific worker could be related to his/her specific workplace, risk analyses should analyze the work task rather than focusing on the individual. Moreover, risk assessments should be performed by using methods that are objective and correct, in other words, reliable and valid. It is of great importance that risk assessment is performed before the work task is taken into production, for example, during the planning stage or when reconstructing existing workplaces. By assessing the wRMSD risk in this stage, it is easier to specify the individual demands that are needed to perform the specific task. Ergonomic risk analyses can also be performed when one aims to evaluate the effect of a workplace intervention. Most studies on effects of workplace interventions 
aim to evaluate the reduction of wrmsDs (8), but this approach is shadowed with a large number of methodological difficulties and it seems to be more feasible to study the effect on ergonomic exposures, rather than the occurrence of injuries.

Using an assembly line as example, workers are exposed to multiple concurrent factors that could lead to wRMSDs, such as the speed and height of the assembly line, the amount of products that are handled, the weight and shape of the products, the weight of the tools used, the duration of the working cycles and the number of pauses. The number of workers on the work site, the number of joints involved, the movement quantity and quality, the ability to alter body positions, psychological stress, time pressure, working hours, time of day, environmental factors (light, temperature, noise, vibrations), and the psychosocial work environment, etc. In a risk assessment of such a complex workplace it is important to structure the exposures into different components based on the pathophysiological mechanisms for WRMSDs. In the best of worlds, a risk assessment should cover all aspects, but often one need to focus on the two or three most important risks in order to find suitable interventions. In a multifactorial environment, one could use one specific assessment method that is perfectly constructed to assess one specific risk in one specific work task over a short time period, or use a general risk assessment method that assesses the total load over a longer time period. So the question is: which approach should be used?

\section{Intensity, Frequency and Duration}

W

hen assessing the ergonomic risks, three key indicators of ergonomic exposure should be taken into account: I) the "intensity" of the work load; e.g. awkward posture of the trunk and/or extremities (posture) ${ }^{3}$ and force production during lifting, pushing and pulling (due to lifting, pushing and pulling tasks), F) the "frequency" of the work load; e.g. repetitive movements, and D) the "duration" of the work load; e.g. static work, lack of changes in posture (9). Using these categories, many of the common ergonomic risks can be identified: manual handling (I), awkward posture (I/D), repetitive work (F), and static work (D) can be observed.

Table 1 provides examples of how these three key indicators of biomechanical exposure can be clustered against the aforementioned ergonomic risks for wRMSDs. This table also shows that many of the common wRMSDs, due to combinations of risks $(6,7)$, can be described by more than one key indicator. Moreover, different and similar categories could be expressed in different or similar measures, making it difficult to know which risk or key indicator is

It is important to understand that posture alone can cause/aggravate wRMSDs due to the weight of the body segments if they are not supported or due to end range positions of the joints involved. 
observed. For example, by measuring the inclination degree of the back during a lifting task (expressed in degrees and in Newtons) in combination with the time spent in this angle (expressed in percentage of working time or in seconds), one could assess the risk level for WRMSDs for the combination of awkward postures and static work. Previous researches show that the combination of risk factors is an especially important factor to consider in a risk assessment [6]. There is in addition a need for observing concurrent risk factors for wRMSDS.

Table 1. Classification of biomechanical loading into the three key indicators (Intensity, Frequency, and Duration) of the ergonomic risks for WRMSDS, their measures and some of the common WRMSDS associated with these exposures.

\begin{tabular}{|c|c|c|c|}
\hline $\begin{array}{c}\text { Key } \\
\text { Indicators }\end{array}$ & Risk & Measure & $\begin{array}{l}\text { Common } \\
\text { WRMSDS }\end{array}$ \\
\hline \multirow{2}{*}{ I: Intensity } & Manual handling & Kg or newton & \multirow{2}{*}{$\begin{array}{c}\text { Injuries in the vertebras } \\
\text { and discs } \\
\text { Injuries in tendons } \\
\text { Injuries in muscles }^{6}\end{array}$} \\
\hline & Awkward posture & Degrees & \\
\hline \multirow{2}{*}{ F: Frequency } & Repetitive work & \multirow{2}{*}{ Cycle time } & \multirow{2}{*}{$\begin{array}{l}\text { Injuries in tendons }{ }^{5} \\
\text { Injuries in muscles }\end{array}$} \\
\hline & Manual handling & & \\
\hline \multirow{2}{*}{ D: Duration } & Static work & $\begin{array}{c}\text { Amount of time } \\
\text { spent in one position, } \\
\text { EMG-level }\end{array}$ & \multirow{2}{*}{$\begin{array}{l}\text { Injuries in tendons } \\
\text { Injuries in muscles }\end{array}$} \\
\hline & Awkward posture & $\begin{array}{c}\text { Number of breaks } \\
\text { Degrees }\end{array}$ & \\
\hline
\end{tabular}

It should be taken into account that the psychosocial (including organizational) factors, individual and environmental factors are not included in this table; these should be incorporated in the overall judgment of the level of the wrmsD risk at a later phase.

\section{Ergonomic Risk Assessment and Intervention}

Frgonomic risk assessment is part of the risk management process that will be included Ein a systematic analysis of potential hazards to ill-health and accidents. The purpose of making an ergonomic risk assessment is to eliminate work-related health risks by identifying existing or potential risks that may lead to msDs. When risk factors are identified, interventions to reduce or minimize them must be carried out. Risk assessments can also be useful to evaluate an intervention performed at the workplace.

\footnotetext{
4 Arthritis/arthrosis, hernia

5 Tendinitis, tendinosis

6 (Semi-)ruptures
} 
To successfully implement ergonomic improvements in the work environment, it is important to identify key persons who have the power and obligations to take action at the workplace at an early stage (10). It is of the outmost importance that the risk assessment is well imbedded in the organization and the key persons are employed by the organization. External consultants could be involved in the ergonomic risk assessment, but the intervention should be initiated from within the organization. Moreover, the employees should be included from the beginning. This so called participatory approach, i.e. where the employees are actively involved in the risk assessment and intervention development, has been proved successful in earlier studies (3).

\section{Four Steps in an Ergonomic Risk Analysis}

T There are four steps involved in an ergonomic risk analysis. First, the physical working situation should map all performed tasks. There are several methods for this, but the hierarchical task analysis (нтА) is a recommended method for this mapping procedure [11]. The next step is to rank the tasks. This can be based on, for example, the time spent on a specific work task, or the severity of the ergonomic problems. This step is followed by an objective assessment of the three key indicators (intensity, frequency and duration) for each work task. Based on the assessment, a decision of the severity of the risk should be taken. A traffic light model - green (no obvious ergonomic problems), yellow/orange (minor/major ergonomic problems) and red (serious ergonomic problems, many workers are at risk of developing wRMSDS) - can be used for this. The fourth and final step is risk management.

In this paper, we focus on the second step, the objective assessment of the ergonomic exposures.

The methods available for the observation of risks can be divided into three categories: questionnaires, observation methods, and technical measurement methods.

1. Questionnaires: Here, the employee assesses the organization ergonomic risks during work using a questionnaire with pre-defined answers, e.g. the Dutch Musculoskeletal Questionnaire (12). This method is easy to use with large groups of workers and enables comparisons over time and between groups. However in workers with wRMsDs, there could be validity problems since they experience their work with a higher perception in terms of intensity, frequency and duration compared to those with no wrMsDs, thus introducing a serious form of bias, i.e. differential exposure assessment bias (13).

2. Observational Methods: These methods have to be based on concepts of an external observer (preferably an ergonomist) who fills in a predefined scoring sheet while watching a worker performing his/her work. These methods are more time-consuming 
but their reliability and validity have been found to be satisfactory (14). Currently, there are many different observational methods for ergonomic risk assessment and no consensus exists on how to choose between them. In 2010, Takala, et al. provided an overview of some of the existing methods (14), but we believe there is a need for an update of this review.

3. Technical Methods: Lately, there has been a large development of new technical methods for observing postures, movements, and loads. For example, there are smartphones applications that can measure angles over time (15), as well as different types of accelerometers (16-18) and inclinometers (19, 20), smart clothing (21), and video-based systems (www.vidarweb.se), etc. that could be used for ergonomic risk assessment. These instruments are usually very accurate, but with some disadvantages: they are more expensive than observational methods, they need to be handled by experts and they interfere with the organization's work.

It is important to choose the most accurate and cost-effective method. We believe that weighing all the pros and cons of these three methods observational methods using pre-defined score sheets seem to be the most useful for ergonomists that work with daily ergonomic risk assessment in work environments.

\section{Aim}

7 he aim of this paper is to give an overview of observation methods that can be used in the assessment of ergonomic risks for wRMSDs at the workplace.

\section{Materials and methods}

\section{Design}

This study was designed as a scoping review of the literature on ergonomic risk assessment. PUBMED, ARBLINE and GOOGLE SCHOLAR databases were searched using combinations of key words such as 'ergonomic risk', 'assessment/measurement/methods', 'WRMSDs', 'intervention', together with the three biomechanical exposure categories, intensity, frequency and duration. Moreover, websites from different national institutions (Sweden) and international (the Netherlands, US) were searched as well. The two authors (WG and EJ) searched for methods using a "snowball method", which means that bibliography of papers 
also were used to find methods. Special focus was put on papers published after 2008, to add methods that were developed after the systematic review of Takala, et al. (2010) (14).

Included were original papers that present the assessment method of the ergonomic risk exposures at work. Only papers in English, Dutch or Swedish that were available in full text were included. Moreover, only methods that use objective assessment measures were included; that is, an external assessor performs the risk assessment based on a pre-defined scoring sheet without the use of technical equipment.

\section{Results}

$\mathrm{I}^{\mathrm{n}}$

n total 19 methods were found that met the inclusion criteria, and for each method, the body part that is assessed together with the key indicators are presented in Table 2. In Appendix 1, the methods are described very briefly. In general, those methods had been found easy to use and provided useful information for the ergonomist to communicate the risk to the employer/employee in terms of green, yellow and red, and gave directions for ergonomic interventions.

Six methods assess risks in all body parts simultaneously (OWAS, PATH, PLIBEL, REBA, RULA, and WERA) while the other 13 methods study specific parts. One method (ALLA) focuses on the lower part of the body, only. Concerning intensity, all instruments measure this key indicator and all but one (HAL) assess the workers' posture. Fourteen of the 19 methods capture the frequency of the work task, while one instrument (кс) only partially assesses frequency, i.e., it asks the examiner with a simple one yes or no question if there were any repetitive movements. Four observation methods (ALLA, LUBA, QEC and RULA) do not include frequency in their risk assessment. Seven methods establishduration (SI, ALLA, HARM, KIM I-II, KIM III, RAMP and WERA) and two methods measure duration only partially (ART, QEC), i.e., if the work task was performed $0-2 \mathrm{~h}, 2-4 \mathrm{~h}$ or $>4 \mathrm{~h} /$ day.

Of the instruments, six assesses all three key indicators: SI, HARM, KIM I-II, KIM III, RAMP and WERA, while one instrument assesses all key issues partly (ART). 
Table 2. Observational Methods for the Assessment of Ergonomic WRMSD Risk

\begin{tabular}{|c|c|c|c|c|}
\hline $\begin{array}{l}\text { Name } \\
\text { and reference }\end{array}$ & Body Part & Intensity & Frequency & Duration \\
\hline ALLA (22) & Lower limb & $\begin{array}{l}\text { Yes } \\
\text { (Posture) }\end{array}$ & No & Yes \\
\hline ART (23) & Mostly hand/ fingers & $\begin{array}{l}\text { Partial } \\
\text { (Posture) }\end{array}$ & Yes & Partial \\
\hline сTD RISK INDEX(24) & Upper extremity & $\begin{array}{l}\text { Yes } \\
\text { (Force and posture) }\end{array}$ & Yes & No \\
\hline HAL (25) & Wrists/hands & $\begin{array}{l}\text { Yes } \\
\text { (Force) }\end{array}$ & Yes & No \\
\hline HARM (26) & $\begin{array}{l}\text { Neck/shoulder, Lower arm/ } \\
\text { wrist }\end{array}$ & $\begin{array}{l}\text { Yes } \\
\text { (Force and posture) }\end{array}$ & Yes & Yes \\
\hline кс (27) & Hand, lower arm & $\begin{array}{l}\text { Yes } \\
\text { (Force and posture) }\end{array}$ & Partial & No \\
\hline $\begin{array}{l}\text { KIM I-II (9) } \\
\text { Lifting/Pulling/Pushing }\end{array}$ & Trunk & $\begin{array}{l}\text { Yes } \\
\text { (Force and posture) }\end{array}$ & Yes & Yes \\
\hline $\begin{array}{l}\text { KIM III (28) } \\
\text { Manual work }\end{array}$ & Arm/wrist & $\begin{array}{l}\text { Yes } \\
\text { (Force and posture) }\end{array}$ & Yes & Yes \\
\hline LUBA (29) & $\begin{array}{l}\text { Neck, shoulders, upper back, } \\
\text { lower back, elbows and } \\
\text { wrists/hands }\end{array}$ & $\begin{array}{l}\text { Yes } \\
\text { (Posture) }\end{array}$ & No & No \\
\hline OCRA (30) & Upper extremity & $\begin{array}{l}\text { Yes } \\
\text { (Force and posture) }\end{array}$ & Yes & No \\
\hline owAS (31) & Whole body & $\begin{array}{l}\text { Yes } \\
\text { (Posture) }\end{array}$ & Yes & No \\
\hline РАТН (32) & Whole body & $\begin{array}{l}\text { Yes } \\
\text { (Force and posture) }\end{array}$ & Yes & No \\
\hline PLIBEL (33) & Whole body & $\begin{array}{l}\text { Yes } \\
\text { (Force and posture) }\end{array}$ & Yes & No \\
\hline QEC (34) & Back, neck, arm, hand & $\begin{array}{l}\text { Yes } \\
\text { (Posture) }\end{array}$ & No & Partial \\
\hline RAMP (35) & Back, upper extremity & $\begin{array}{l}\text { Yes } \\
\text { (Force and posture) }\end{array}$ & Yes & Yes \\
\hline REBA (36) & Whole body & $\begin{array}{l}\text { Yes } \\
\text { (Posture) }\end{array}$ & No & No \\
\hline RULA (37) & Upper extremity/Whole body & $\begin{array}{l}\text { Yes } \\
\text { (Posture) }\end{array}$ & No & No \\
\hline SI (38) & Hand, lower arm & $\begin{array}{l}\text { Yes } \\
\text { (Posture) }\end{array}$ & Yes & Yes \\
\hline WERA (39) & Whole body & $\begin{array}{l}\text { Yes } \\
\text { (Force and posture) }\end{array}$ & Yes & Yes \\
\hline
\end{tabular}




\section{Discussion}

This study maps a large number of instruments that can be used in the assessment of ergonomic wrMsD risk factors. Table 2 shows an overview of which body parts and key indicators (I, F, D) are assessed by these instruments. All of the instruments assess posture (intensity), but the other two key issues of biomechanical exposure (frequency and duration) were not included in all observational methods. Considering the instruments, only six assess all three key indicators: SI, HARM, KIM I-II and KIM III, RAMP and WERA, and among these, only WERA measures the biomechanical WRMSD risk for all body parts.

For ergonomists that perform risk assessments, there is a large number of observational assessment tools available, it is important to understand that different methods can be used simultaneously in order to estimate the objective wRMSD risk levels.

\section{Acknowledgements}

The authors wish to thank Amanda Hansson for her valuable input on the manuscript.

\section{References}

1. Dul J, Bruder R, Buckle P, Carayon P, Falzon P, Marras WS, et al. A Strategy for Human Factors/Ergonomics: Developing the Discipline and Profession. Ergonomics. 2012;55(4):377-95.

2. Verbeek J, Pulliainen M, Kankaanpaa E. A Systematic Review of Occupational Safety and Health Business Cases. Scandinavian journal of work, environment \& health. 2009;35(6):403-12.

3. Rivilis I, Van Eerd D, Cullen K, Cole DC, Irvin E, Tyson J, et al. Effectiveness of Participatory Ergonomic Interventions on Health Outcomes: a Systematic Review. Appl Ergon. 2008;39(3):342-58.

4. IAE. International Encyclopedia of Ergonomics and Human Factors. $2^{\text {nd }}$ edition ed. Boca Raton, London, New York: Taylor \& Francis; 2006.

5. Nyman T, Grooten WJ, Wiktorin C, Liwing J, Norrman L. Sickness Absence and Concurrent Low Back and Neck-Shoulder Pain: Results from the MUSIC-Norrtalje Study. Eur Spine J. 2007;16(5):631-8. 
6. Grooten WJ, Wiktorin C, Norrman L, Josephson M, Tornqvist EW, Alfredsson L. Seeking Care for Neck/Shoulder Pain: a Prospective Study of Work-Related Risk Factors in a Healthy Population. Journal of Occupational and Environmental Medicine / American College of Occupational and Environmental Medicine. 2004;46(2):138-46.

7. Grooten WJ, Mulder M, Josephson M, Alfredsson L, Wiktorin C. The Influence of Work-Related Exposures on the Prognosis of Neck/Shoulder Pain. Eur Spine J. 2007;16(12):2083-91.

8. Grooten WJ, Mulder M, Wiktorin C. The Effect of Ergonomic Intervention on Neck/ Shoulder and Low Back Pain. Work. 2007;28(4):313-23.

9. Steinberg U. New Tools in Germany: Development and Appliance of the First Two KIM ("Lifting, Holding and Carrying" and "Pulling and Pushing") and Practical Use of These Methods. Work. 2012;41 Suppl 1:3990-6.

10. Berlin C, Neumann WP, Theberge N, Örtengren R. Avenues of Entry: How Industrial Engineers and Ergonomists Access and Influence Human Factors and Ergonomics Issues. European Journal of Industrial Engineering. 2014;8(3):325-48.

11. Stanton NA. Hierarchical Task Analysis: Developments, Applications, and Extensions. Appl Ergon. 2006;37(1):55-79.

12. Hildebrandt VH, Bongers PM, van Dijk FJ, Kemper HC, Dul J. Dutch. Musculoskeletal Questionnaire: Description and Basic Qualities. Ergonomics. 2001;44(12):1038-55.

13. Wiktorin C, Karlqvist L, Winkel J. Validity of Self-Reported Exposures to Work Postures and Manual Materials Handling. Stockholm MUSIC I Study Group. Scandinavian journal of work, environment \& health. 1993;19(3):208-14.

14. Takala EP, Pehkonen I, Forsman M, Hansson GA, Mathiassen SE, Neumann WP, et al. Systematic Evaluation of Observational Methods Assessing Biomechanical Exposures at Work. Scandinavian journal of work, environment \& health. 2010;36(1):3-24.

15. Yang L, Grooten WJA, Forsman M. An iPhone Application for Upper Arm Posture and Movement Measurements. Appl Ergon. 2017;65:492-500.

16. Bernmark E, Wiktorin C. A Triaxial Accelerometer for Measuring Arm Movements. Appl Ergon. 2002;33(6):541-7.

17. Peterson NE, Sirard JR, Kulbok PA, DeBoer MD, Erickson JM. Validation of Accelerometer Thresholds and Inclinometry for Measurement of Sedentary Behavior in Young Adult University Students. Res Nurs Health. 2015;38(6):492-9.

18. Welk GJ, Blair SN, Wood K, Jones S, Thompson RW. A Comparative Evaluation of Three Accelerometry-Based Physical Activity Monitors. Medicine and science in Sports and Exercise. 2000;32(9):S489-97.

19. Bucke J, Spencer S, Fawcett L, Sonvico L, Rushton A, Heneghan NR. Validity of the Digital Inclinometer and iPhone When Measuring Thoracic Spine Rotation. Journal of athletic training. 2017. 
20. Camargo PR, Phadke V, Zanca GG, Ludewig PM. Concurrent Validity of Inclinometer Measures of Scapular and Clavicular Positions in Arm Elevation. Physiother Theory Pract. 2017:1-10.

21. Yapici MK, Alkhidir TE. Intelligent Medical Garments with Graphene-Functionalized Smart-Cloth ECG sensors. Sensors. 2017;17(4).

22. Kong YK, Lee SY, Lee KS, Kim DM. Comparisons of Ergonomic Evaluation Tools (ALLA, RULA, REBA and OWAS) for Farm Work. International Journal of Occupational Safety and Ergonomics : JOSE. 2017:1-6.

23. Ferreira J, Gray M, Hunter L, Birtles M, Riley D. Development of an Assessment Tool for Repetitive Tasks of the Upper Limbs (ART). 2009.

24. Seth V, Weston RL, Freivald A. Development of a Cumulative Trauma Disorder Risk Assessment Model for the Upper Extremities. Int J Ind Ergonom. 2015;23:281-91.

25. Garg A, Kapellusch J, Hegmann K, Wertsch J, Merryweather A, Deckow-Schaefer G, et al. The Strain Index (sI) and Threshold Limit Value (TLV) for Hand Activity Level (hAL): Risk of Carpal Tunnel Syndrome (стs) in a Prospective Cohort. Ergonomics. 2012;55(4):396-414.

26. Douwes M, de Kraker H. HARM Overview and its Application: Some Practical Examples. Work. 2012;41 Suppl 1:4004-9.

27. Keyserling WM, Stetson DS, Silverstein BA, Brouwer ML. A Checklist for Evaluating Ergonomic Eisk Eactors Essociated with Upper Extremity Cumulative Trauma Disorders. Ergonomics. 1993;36(7):807-31.

28. Klussmann A, Gebhardt H, Rieger M, Liebers F, Steinberg U. Evaluation of Objectivity, Reliability and Criterion Validity of the Key Indicator Method for Manual Handling Operations (кім -мно), draft 2007. Work. 2012;41 Suppl 1:3997-4003.

29. Kee D, Karwowski W. Luba: An Assessment Technique for Postural Loading on the Upper Body Based on Joint Motion Discomfort and Maximum Holding Time. Appl Ergon. 2001;32(4):357-66.

30. Occhipinti E, Colombini D. [Proposal of a Concise Index for the Evaluation of the Exposure to Repetitive Movements of the Upper Extremity (ocRA index)]. La Medicina del lavoro. 1996;87(6):526-48.

31. Karhu O, Kansi P, Kuorinka I. Correcting Working Postures in Industry: A Practical Method for Analysis. Appl Ergon. 1977;8(4):199-201.

32. Buchholz B, Paquet V, Punnett L, Lee D, Moir S. РAтн: A Work Sampling-Based Approach to Ergonomic Job Analysis for Construction and other Non-Repetitive Work. Appl Ergon. 1996;27(3):177-87.

33. Kemmlert K. A Method Assigned for the Identification of Ergonomic Hazards - PLIBEL. Appl Ergon. 1995;26(3):199-211.

34. McAtamney L, Li G, Buckle P. Quick Exposure Checklist (QEC) for the Assessment of Workplace Risks for Work-Related Musculoskeletal Disorders (wRMsDs). In: Stanton N, 
editor. Handbook of Human Factors and Ergonomics Methods. Boca Raton: CRC Press LLC; 2005. p. 48-60.

35. Lind CM. Pushing and Pulling: an Assessment Tool for Occupational Health and Safety Practitioners. International journal of Occupational Safety and Ergonomics: JOSE. 2016:1-13.

36. Hignett S, McAtamney L. Rapid Entire Body Assessment (rebA). Appl Ergon. 2000;31(2):201-5.

37. McAtamney L, Nigel Corlett E. RULA: a Survey Method for the Investigation of WorkRelated Upper Limb Disorders. Appl Ergon. 1993;24(2):91-9.

38. Moore JS, Garg A. The Strain Index: a Proposed Method to Analyze Jobs for Risk of Distal Upper Extremity Disorders. American Industrial Hygiene Association Journal. 1995;56(5):443-58.

39. Abd Rahman MN, Abdul Rani MR, Rohani JM. werA: An Observational Tool Develop to Investigate the Physical Risk Factor Associated with wRMSDs. Journal of Human Ergology. 2011;40(1-2):19-36.

40. Kong YK, Lee KS, Han JG, Kim DM. Development of an Ergonomic Checklist for the Investigation of Work-Related Upper Limb Disorders in Farming - AULA: Agricultural Upper-Limb Assessment. Journal of the Ergonomics Society of Korea 2011;30(4):481-9. 


\section{Appendix 1. Short description of the observational methods}

\section{Agricultural Lower Limb Assessment - ALLA}

ALLA is a diverse and segmented ergonomic lower limb assessment tool developed for farm assessing farmers at work. ALLA is especially useful for studying lower limb burdening work [22, 40].

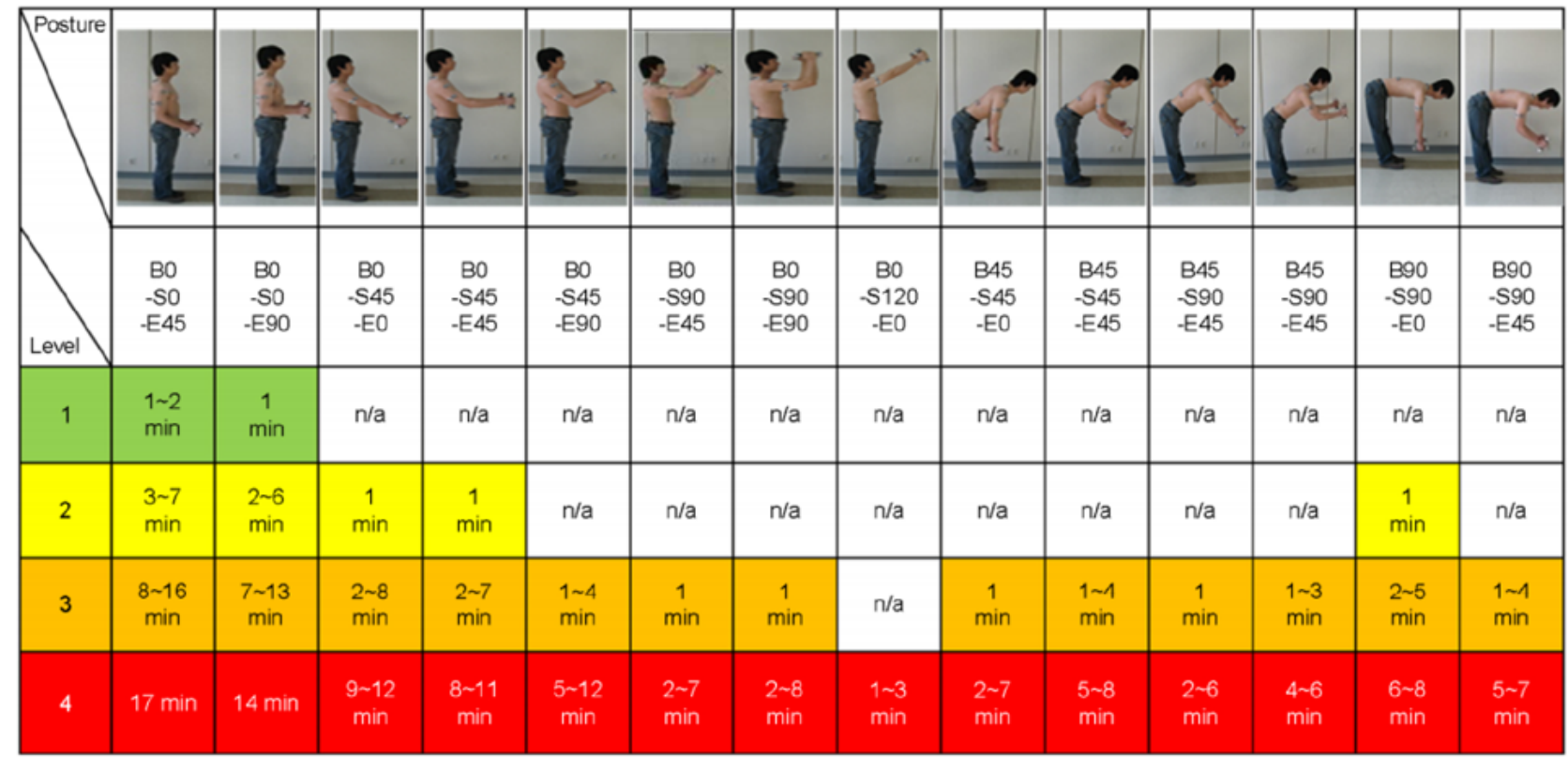

\begin{tabular}{|c|c|c|c|c|}
\hline Level & 1 & 2 & 3 & 4 \\
\hline Risk level & Medium & Little High & High & Very High \\
\hline
\end{tabular}

Source: http://www.koreascience.or.kr/article/ArticleFullRecord.jsp?cn=OGGHBK_2010_v29n6_933

\section{Assessment of Repetitive Task of the upper limbs - ART}

ART is suited for tasks that involve actions of the upper limbs that are repeated every few minutes, or even more frequently, and occur for at least 1-2 hours per day or shift. Although ART mainly focuses on upper limbs, neck and back positions are monitored as well. The risk levels for the following factors are assessed: frequency and repetition of movements, power, work postures and influencing factors. If the predetermined risk levels do not fit, the assessment can be placed between two levels. ART can be used in assembly line, production, processing, packaging, packing and sorting work, as well as work involving the regular use of hand tools. ART is not intended for display screen equipment (DSE) assessments. ART has developed an excel sheet for analyzing several tasks that take into account the rotation frequency between different tasks (23). 


\section{Flow chart}
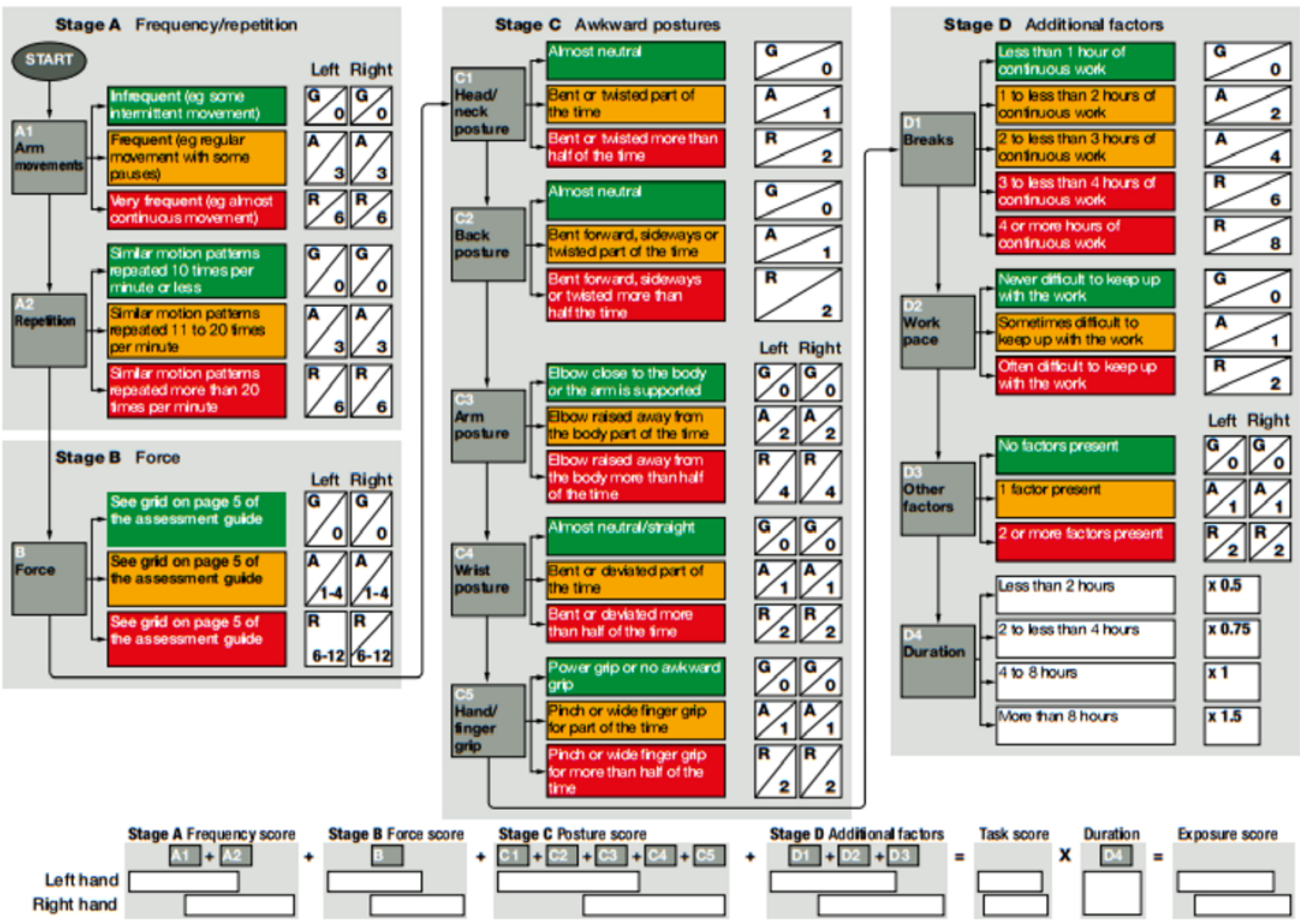

Source: http://www.hse.gov.uk/pubns/indg438.pdf

\section{Cumulative Trauma Disorder - CDT}

The instrument was developed for the detection of repetitive strain injuries and includes four main factors that contribute to a sum score (based on a specific equation): the frequency, posture, force and miscellaneous factors (24). 
CTD Risk Index

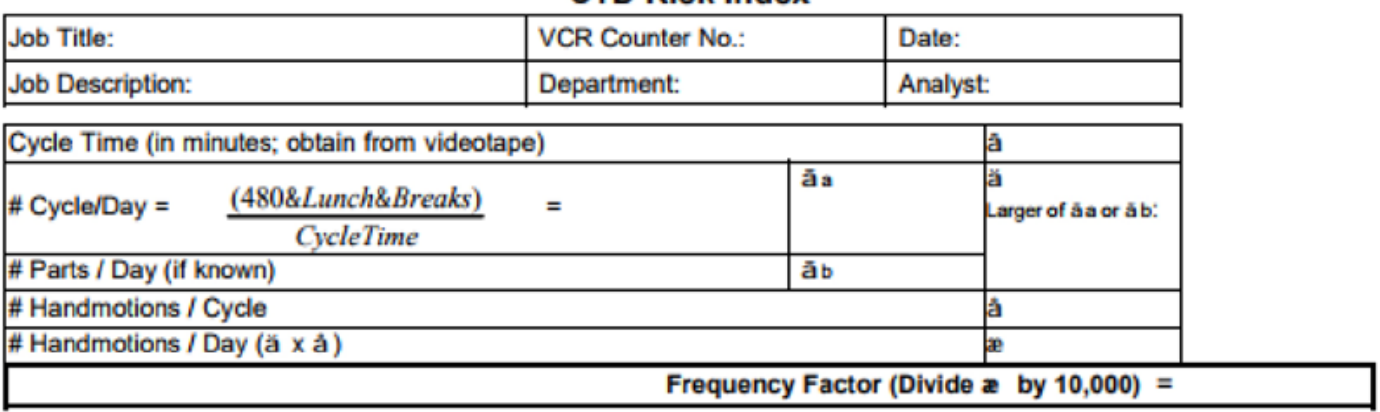

\begin{tabular}{|c|c|c|c|c|}
\hline \multirow{2}{*}{ (Circle appropriate condition) } & \multicolumn{4}{|c|}{ Points } \\
\hline & 0 & 1 & 2 & 3 \\
\hline Working Posture & Sit & Stand & & \\
\hline Hand Posture 1: Pulp Pinch & No & Yes & & \\
\hline Hand Posture 2: Lateral Pinch & No & Yes & & \\
\hline Hand Posture 3: Palm Pinch & No & Yes & & \\
\hline Hand Posture 4: Finger Press & No & Yes & & \\
\hline Hand Posture 5: Power Grip & Yes & No & & \\
\hline Type of Reach & Horizontal & Up/Down & & \\
\hline Hand Deviation 1: Flexion & No & Yes & & \\
\hline Hand Deviation 2: Extension & No & Yes & & \\
\hline Hand Deviation 3: Radial Dev. & No & Yes & & \\
\hline Hand Deviation 4: Ulnar Dev. & No & Yes & & \\
\hline Forearm Rotation & Neutral & In/Out & & \\
\hline Elbow Angle & $\cdot 90 \mathrm{E}$ & -90E & & \\
\hline Shoulder Abduction & 0 & $\angle 45 E$ & $<90 \mathrm{E}$ & $>90 E$ \\
\hline Shoulder Flexion & 0 & $<90 \mathrm{E}$ & $<180 E$ & $>180 E$ \\
\hline Back/Neck Angle & 0 & $\angle 45 E$ & $<90 \mathrm{E}$ & $>90 E$ \\
\hline Balance & Yes & No & & \\
\hline & & Points fo & ded C & c \\
\hline
\end{tabular}

\begin{tabular}{|c|c|}
\hline Grip or Pinch Force Used on Task & lbs. ế Dividee byé: \\
\hline Max Grip or Pinch Force & Ibs. \\
\hline
\end{tabular}

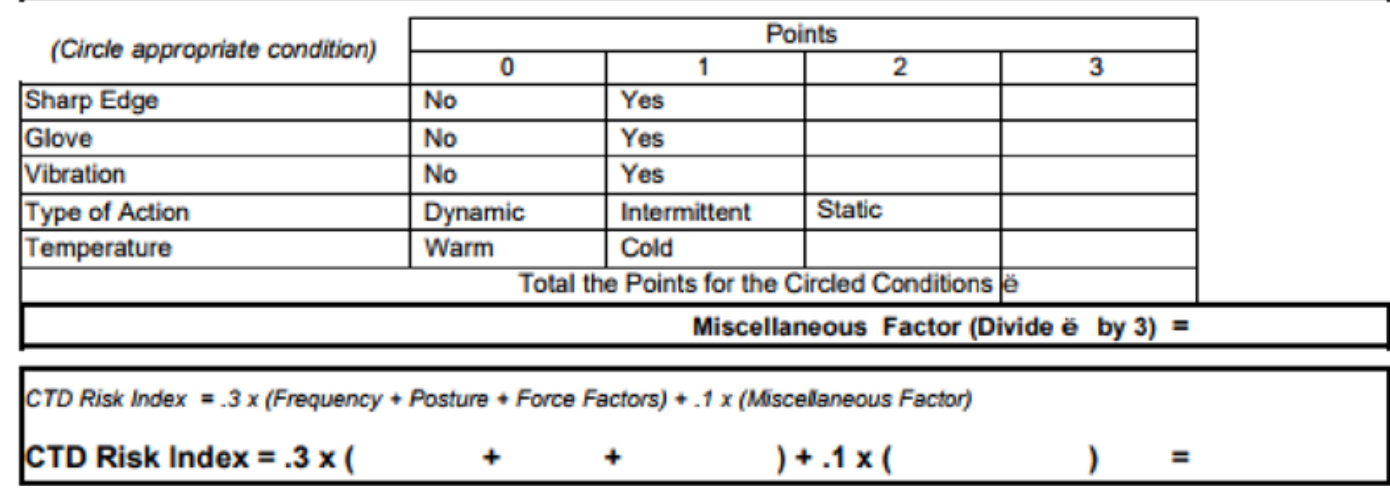

Source: http://home.spin.net.au/safehands/reference\%20documents/CTDRisk.pdf

\section{Hand Activity Level}

This method intends to assess the MSD risk in the hand and forearm in repetitive work that is performed for at least four hours. The method is based on two variables that are judged by simple observations and estimates of the person performing the work: 1) hand activity 
level (HAL), that indicates how often the movements are performed (assessed on a vas scale), and 2) hand force, in which the produced force is estimated with a Borg CR-10 scale. These variables are placed on two axes in a chart with marked areas for red, yellow and green for identification of action and threshold limit values (TLV) (25).

\begin{tabular}{|c|c|c|c|c|c|}
\hline \multirow{2}{*}{\multicolumn{3}{|c|}{ Job }} & \multirow[t]{2}{*}{ Analyst } & \multirow{2}{*}{\multicolumn{2}{|c|}{ Date }} \\
\hline & & & & & \\
\hline \multicolumn{3}{|c|}{$\begin{array}{l}\text { Hand Activity Level (HAL) } \\
\text { (See scale below) }\end{array}$} & & & \\
\hline \multicolumn{3}{|c|}{$\begin{array}{l}\text { Normalized Peak Force (NPF) } \\
\text { (See table below) }\end{array}$} & & & \\
\hline \multicolumn{3}{|c|}{ Ratio = NPF / (10-HAL) } & & & \\
\hline \multicolumn{2}{|c|}{ Determine Result } & $\begin{aligned} \mathrm{TLV} & =0.78 \\
\mathrm{AL} & =0.56\end{aligned}$ & $\begin{array}{r}>\mathrm{TLV} \\
\mathrm{AL} \text { to TLV } \\
<\mathrm{AL}\end{array}$ & $\begin{array}{l}> \\
\text { AL to }\end{array}$ & $\begin{array}{l}\text { ILV } \\
\text { ILV } \\
\text { AL }\end{array}$ \\
\hline \multicolumn{6}{|c|}{ Hand Activity Level Rating } \\
\hline $\begin{array}{c}0 \\
\text { Hands idle } \\
\text { most of the } \\
\text { time; no } \\
\text { regular } \\
\text { exertions }\end{array}$ & $\begin{array}{l}1 \\
2 \\
\text { Consistent } \\
\text { conspicuous } \\
\text { long pauses; or } \\
\text { very slow } \\
\text { motions }\end{array}$ & $\begin{array}{c}\mid \\
4 \\
\text { Slow steady } \\
\text { motion/exer- } \\
\text { tions; frequent } \\
\text { brief pauses }\end{array}$ & $\begin{array}{c}\mid \\
6 \\
\text { Steady motion/ } \\
\text { exertion; } \\
\text { infrequent } \\
\text { pauses }\end{array}$ & $\begin{array}{c}1 \\
8 \\
\text { Rapid steady } \\
\text { motion/exer- } \\
\text { tions; no } \\
\text { regular pauses }\end{array}$ & $\begin{array}{l}10 \\
\text { Rapid steady } \\
\text { motion/ } \\
\text { difficulty } \\
\text { keeping up or } \\
\text { continuous } \\
\text { exertion }\end{array}$ \\
\hline
\end{tabular}

\begin{tabular}{|c|c|c|c|c|}
\hline \multirow{3}{*}{$\% M V C$} & \multicolumn{3}{|c|}{ Estimation of Normalized Peak Force for Hand Forces } & \multirow{3}{*}{$N P F$} \\
\hline & \multicolumn{2}{|c|}{ Subjective Scale } & \multirow{2}{*}{$\begin{array}{c}\text { Moore-Garg Observer Scale } \\
\text { (Alternative Method) }\end{array}$} & \\
\hline & Score & Verbal Anchor & & \\
\hline 0 & 0 & Nothing at all & & 0 \\
\hline 5 & 0.5 & $\begin{array}{l}\text { Extremely Weak } \\
\text { (Just Noticeable) }\end{array}$ & Barely Noticeable or Relaxed Effort & 0.5 \\
\hline 10 & 1 & Very Weak & & 1 \\
\hline 20 & 2 & \begin{tabular}{|l|} 
Weak (Light) \\
\end{tabular} & Noticeable or Definite Effort & 2 \\
\hline 30 & 3 & Moderate & & 3 \\
\hline 40 & 4 & & $\begin{array}{l}\text { Obvious Effort, But Unchanged Facial } \\
\text { Expression }\end{array}$ & 4 \\
\hline 50 & 5 & Strong (Heavy) & & 5 \\
\hline 60 & 6 & & Substantial Effort with Changed Facial & 6 \\
\hline 70 & 7 & Very Strong & Expression & 7 \\
\hline 80 & 8 & & & 8 \\
\hline 90 & 9 & & Uses Shoulder or Truck for Force & 9 \\
\hline 100 & 10 & $\begin{array}{l}\begin{array}{l}\text { Extremely Strong } \\
\text { (almost maximum) }\end{array} \\
\end{array}$ & & 10 \\
\hline
\end{tabular}

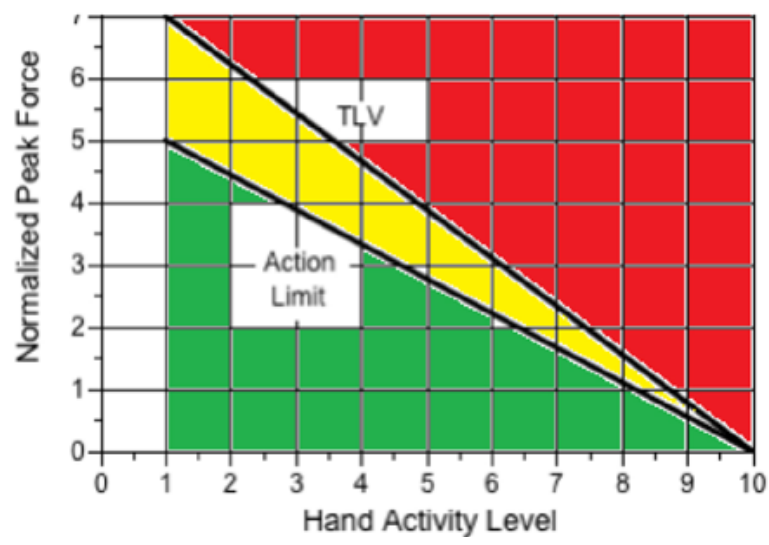

Source: http://personal.health.usf.edu/tbernard/HollowHills/HALTLVM15.pdf 


\section{HARM}

HARM assesses the risk of load-related injuries in the hand, arm, shoulder and neck during work tasks that last for at least one hour while the weight of what is handled is less than 6 $\mathrm{kg}$. The method is intended to be used only for manual and arm-intensive work. It should not be used for assessing computer work. The assessment is conducted on one work task at the time, i.e., if there are several hand-intensive tasks within the work, they are assessed separately. HARM assesses six different areas: time, most active hand, power, work posture, vibration, and other factors. For these areas, different risk points are calculated, which are finally combined, resulting in a risk assessment. Risk levels are graded in green, yellow or red (26). The assessment form is a five-page document, alternatively it is a computerized tool.

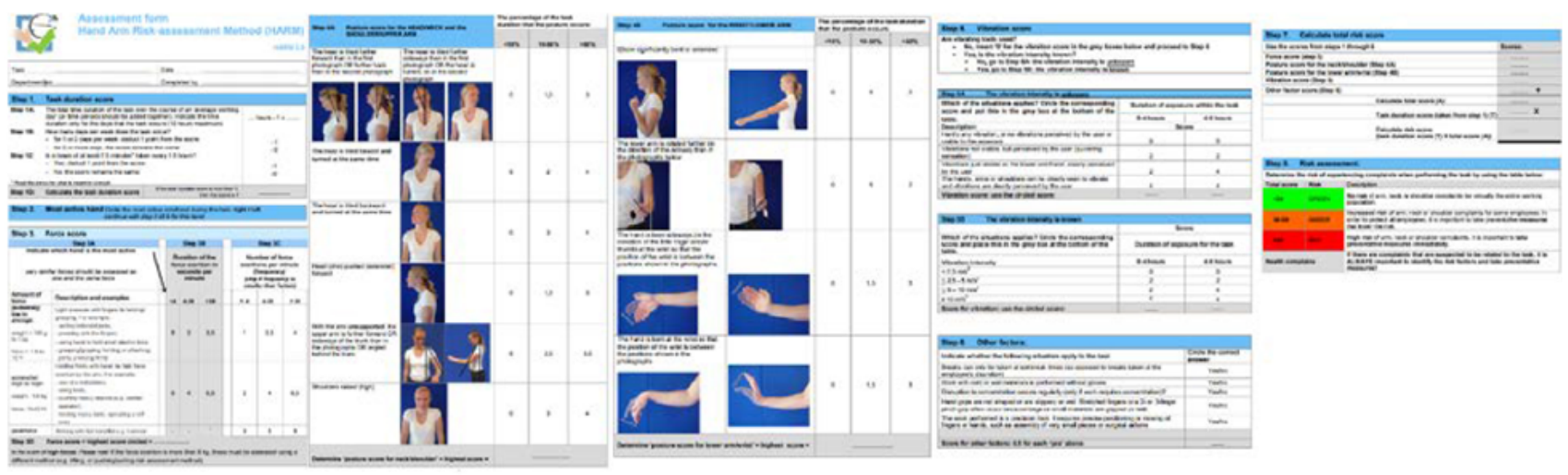

Source: https://www.fysiekebelasting.tno.nl/en/instrumenten/welcome-to-the-hand-arm-risk-assessment-method-harm/

\section{Keyserlings Cumulative Trauma Checklist}

кс was developed to map the risk factors associated with мsDs in the upper extremities aiming to reduce accidents and inconvenience caused by poor ergonomics at the workplace in a car factory. кс assesses the occurrence of awkward posture, repetitive movements, external forces, vibration, temperature, drafts, tools, and glove use on 18 yes/no questions for both hands. For some factors, duration and frequency are also noted. A total sum score is obtained, the risks are graded into three levels (27). 


\section{Keyserlings checklista för övre extremiteterna}

\begin{tabular}{|l|l|l|l|l|}
\hline \multicolumn{2}{|l|}{ Företag/Arbetsplats/Arbetsmoment } & Bedömare \\
\hline Arbetstagare & & Datum för bedömningen \\
\hline Vilken är arbetstagarens dominanta hand? & Vänster & Höger & Båda & \multicolumn{1}{|l|}{} \\
\hline
\end{tabular}

Besvara nedanstående frågor genom att ringa in lämpligt alternativ

Repetitivitet

1. Innehåller arbetet repetitiva handrörelser?

Nej Ja

Besvara "ja" om något av följande stämmer:

a. arbetscykeln är kortare än 30 sek, eller

b. händerna repeterar samma rörelser under mer än halva arbetscykeln

Mekanisk stress

2. Orsakar hårda eller skarpa föremål, verktyg eller delar av arbetsytan lokalt tryck på:

a. fingrarnas dorsal- eller lateralsida?

b. handflata eller handledsbas?

c. underarm eller armbåge?

d. armhåla?

\begin{tabular}{llll}
\multicolumn{2}{c}{ Vănster hand } & \multicolumn{2}{c}{ Höger hand } \\
Nej & Ja & Nej & Ja \\
0 & V & 0 & V \\
0 & V & 0 & V \\
0 & V & 0 & V \\
0 & V & 0 & V
\end{tabular}

3. Används handflatan eller hypotenarregionen som "slagverktyg" (hammare)?

0

$\checkmark$

0

v

Kraftanvăndning

4. Lyfter, băr, skjuter/pressar eller drar arbetstagaren objekt som văger mer ăn $4,5 \mathrm{~kg}$ ?

5. Måste arbetstagaren greppa objekt, verktyg eller redskap som har slät och hal yta (ingen ytstruktur eller făste för att minska risken att glida)?

6. Används fingertoppen eller tummen för att pressa, trycka eller skjuta?

7. Om inga handskar anvănds sätt kryss i rutan och gå vidare till frăga 8 .

Om arbetstagaren använder handskar, försvárar då dessa hans greppmöjlighet?

0

V

0

$\checkmark$ 


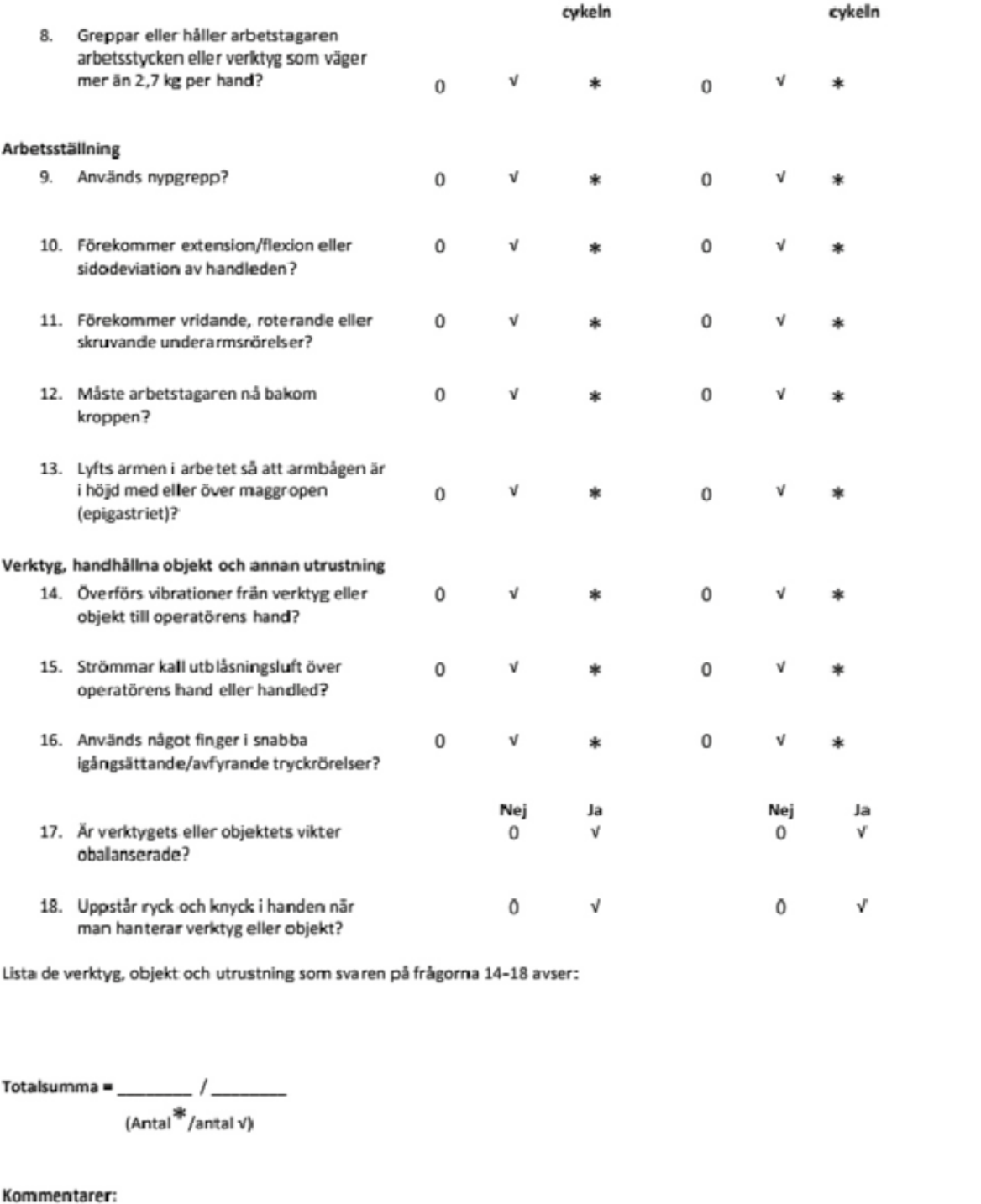

\section{KIM I (Lifting) and KIM II (Push and Pull)}

KIM I is designed for assessment of work tasks that require manual handling during a working day. First, it determines if manual handling primarily involves lifting/holding, holding or carrying loads. This gives a time span. Then the weight of the load is established. The most common job posture is determined as well as various aggravating factors. Finally, a risk point is calculated. Risk levels are graded in green, yellow, orange or red (9). 

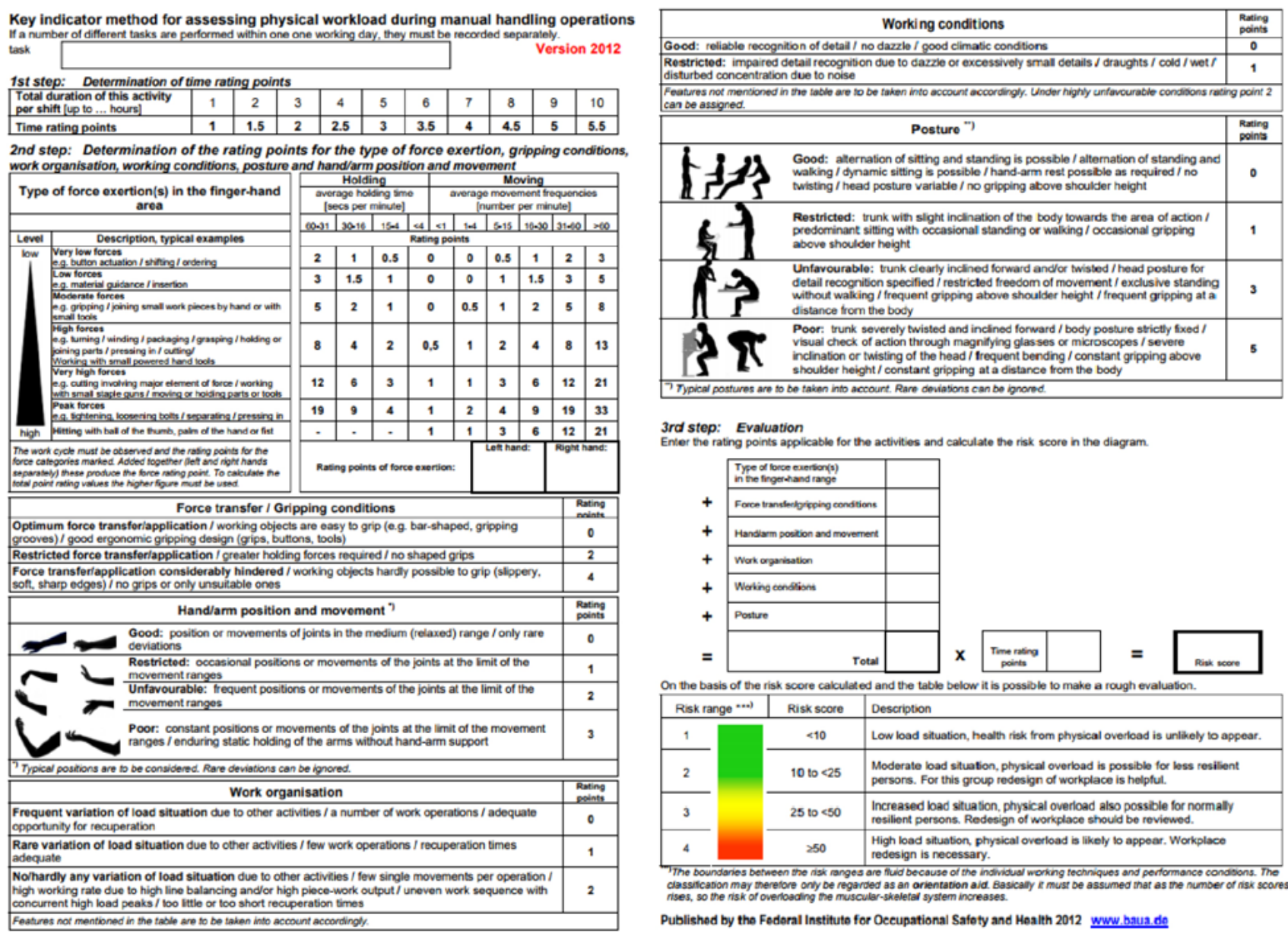

3rd step: Evaluation

Enter the rating peints apolicable for the activites and calculate the risk score in the diagram.
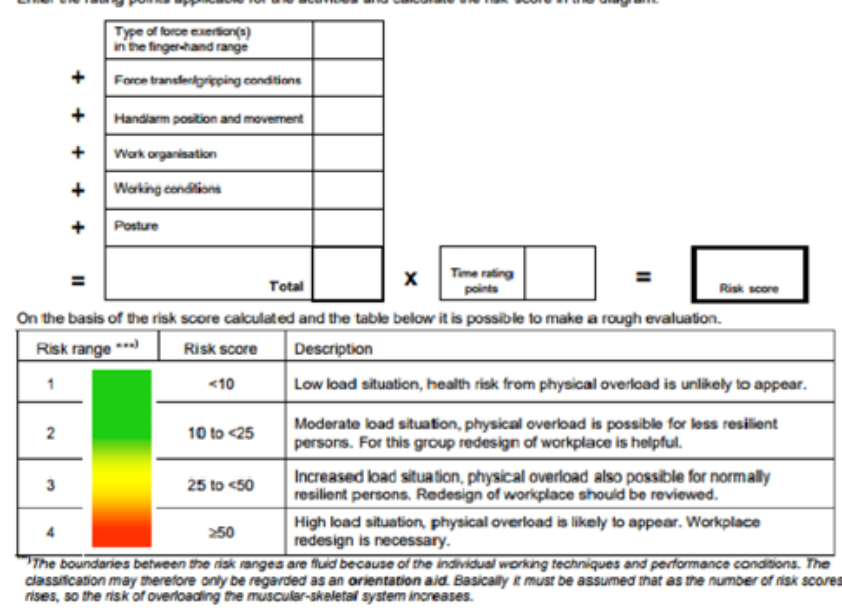

Published by the Fedoral Institute for Oceupational Safoty and Health 2012 www. baus.den

Source: https://www.baua.de/DE/Themen/Arbeitsgestaltung-im-Betrieb/Physische-Belastung/Leitmerkmalmethode/pdf/KIMmanual-handling-2.pdf?__blob=publicationFile

In a similar way, KIM II is used for assessment of work that involves pushing and pulling. The procedure is similar to KIM I. First, a time point is given, based on the distance that the load is moved (more or less than $5 \mathrm{~m}$ ). Then, the weight of the load and how it is moved is determined. If the work involves load pushing, the body posture is assessed. Movement speed and body posture are also determined, as well as aggravating factors. Finally, a sum of risk points is calculated. Risk levels are graded in green, yellow, orange or red (9). 
Assessment of pulling and pushing based on key indicators Version Sept 2002

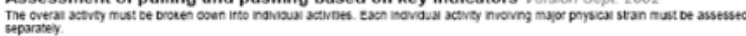
Workelace/Activity:

\begin{tabular}{|c|c|c|c|}
\hline \multicolumn{2}{|c|}{$\begin{array}{l}\text { Pulling and pushing over short distances or fre-- } \\
\text { quent stopping (single distanoe up to } 5 \text { metres) }\end{array}$} & \multicolumn{2}{|c|}{$\begin{array}{l}\text { Pulling and pushing over longer distances (sin- } \\
\text { gle distanoe more than } 5 \text { metres) }\end{array}$} \\
\hline Number on working ary & Time ratng points & 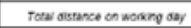 & Time rasnop ponsts \\
\hline$<10$ & 1 & $<300 \mathrm{~m}$ & 1 \\
\hline 10 b $<40$ & 2 & $300 \mathrm{~m}$ to $<1 \mathrm{~km}$ & 2 \\
\hline 40 to $<200$ & 4 & $1 \mathrm{~km}$ to $<4 \mathrm{~km}$ & 4 \\
\hline 200 ts $<800$ & 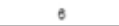 & 4 to $<\theta \mathrm{km}$ & e \\
\hline 600 to $<1000$ & 8 & $810<16 \mathrm{~km}$ & 8 \\
\hline$=1000$ & 10 & $=16 \mathrm{~km}$ & 10 \\
\hline \multicolumn{2}{|c|}{ 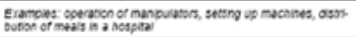 } & \multicolumn{2}{|c|}{ 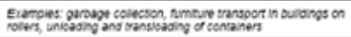 } \\
\hline
\end{tabular}

2nd step: Determination of rating points of mass, positioning accuracy, speed, pos.

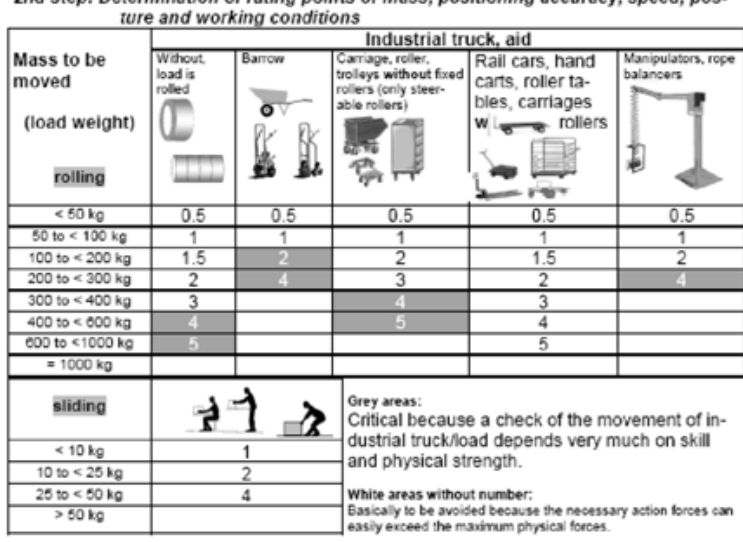

\begin{tabular}{|c|c|c|}
\hline \multirow[b]{2}{*}{ Positioning accuracy } & \multicolumn{2}{|c|}{ Speed of motion } \\
\hline & $(<08 \mathrm{mis})$ & $\begin{array}{c}\text { fost } \\
(0.30513 \mathrm{~m} / \mathrm{s})\end{array}$ \\
\hline $\begin{array}{l}\text { Low } \\
\text { - no specifoation of travelling distance } \\
\text { - load can rollt to a stop or runs a a ainst a stop }\end{array}$ & 1 & 2 \\
\hline $\begin{array}{l}\text { High } \\
\text { - load must be accurately positioned and stopped } \\
\text { - traveling distance must be adhered to exacty } \\
\text { - frequent changes in direction }\end{array}$ & 2 & 4 \\
\hline
\end{tabular}
frequent ehanges in dicector

Source: http://www.ammuppsala.se/kim-ii

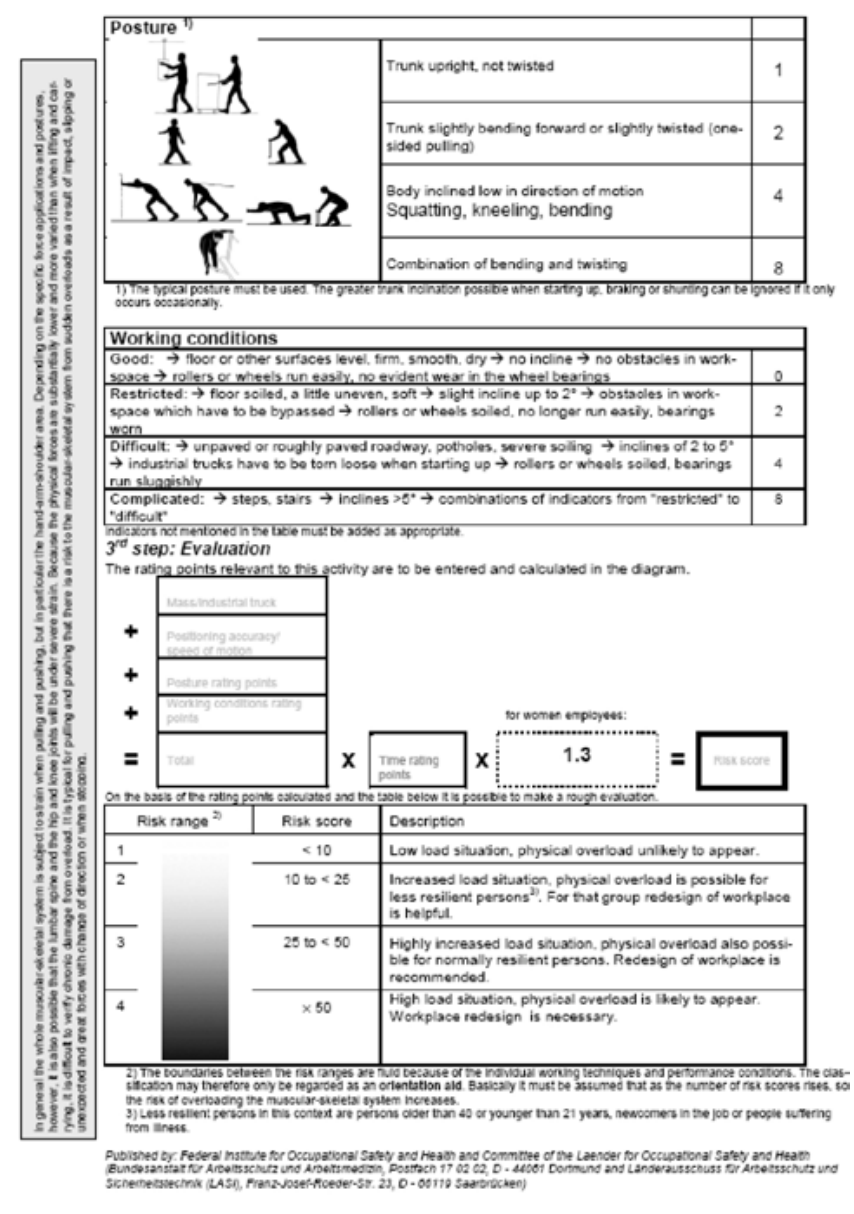

\section{KIM III (Repetitive Manual Handling for the Hand-Arm)}

кIM III is developed after кIM I and II, it assesses repetitive manual handling for the hand-arm. The latest validated version was published in 2012. The analysis is based on observation of several working cycles. If the cycle time is less than 60 seconds, 5-10 cycles are observed. If the cycle time is longer than 60 seconds, 10-15 cycles are observed. The duration of the activity over a working day, the effort needed, position of hand and arm, work organization, body posture etc. are determined. Risk levels are graded in green, yellow, orange or red (28).

\section{Loading on the Upper Body Assessment - LUBA}

In LUBA, a score is calculated for the posture of each body part. The combined individual score for the neck, shoulders, upper back, lower back, elbows and wrists/hands gives a postural load index (PLI). This pLI score shows how musculoskeletal loading is associated to the worker's posture. LUBA classifys the risk of musculoskeletal disorders into four action categories (29). 


\begin{tabular}{|c|c|c|c|c|c|c|c|c|}
\hline \multicolumn{2}{|c|}{$\begin{array}{l}\text { Department: } \\
\text { Analyst name: }\end{array}$} & \multicolumn{3}{|c|}{ Task: } & \multicolumn{4}{|c|}{$\begin{array}{l}\text { Operator: } \\
\text { Date: }\end{array}$} \\
\hline Joint & Motion & Class & Score & & Motion & Class & Score & \\
\hline \multirow[t]{6}{*}{ Wrist } & Flexion & $0-20^{\circ}$ & 1 & - & Extension & $0-20^{\circ}$ & 1 & - \\
\hline & & $20-60^{\circ}$ & 4 & - & & $20-45^{\circ}$ & 5 & - \\
\hline & & $>60^{\circ}$ & 9 & - & & $>45^{\circ}$ & 11 & - \\
\hline & Radial & $0-10^{\circ}$ & 1 & - & Ulnar & $0-10^{\circ}$ & 1 & - \\
\hline & deviation & $10-30^{\circ}$ & 5 & - & deviation & $10-20^{\circ}$ & 5 & - \\
\hline & & $>30^{\circ}$ & 10 & - & & $>20^{\circ}$ & 9 & - \\
\hline \multirow[t]{5}{*}{ Elbow } & Flexion & $0-45^{\circ}$ & 1 & - & Supination & $0-90^{\circ}$ & 3 & - \\
\hline & & $45-120^{\circ}$ & 3 & - & & $>90^{\circ}$ & 9 & - \\
\hline & & $>120^{\circ}$ & 7 & - & & & & \\
\hline & Pronation & $0-70^{\circ}$ & 3 & - & & & & \\
\hline & deviation & $>70^{\circ}$ & 9 & - & & & & \\
\hline \multirow[t]{10}{*}{ Shoulder } & Flexion & $0.45^{\circ}$ & 1 & - & Extension & $0-20^{\circ}$ & 1 & - \\
\hline & & $45-90^{\circ}$ & 5 & - & & $20-45^{\circ}$ & 7 & - \\
\hline & & $90-150^{\circ}$ & 9 & - & & $45-60^{\circ}$ & 12 & - \\
\hline & & $>150^{\circ}$ & 14 & - & & $>60^{\circ}$ & 16 & - \\
\hline & Adduction & $0-10^{\circ}$ & 1 & - & Abduction & $0-30^{\circ}$ & 1 & - \\
\hline & & $10-30^{\circ}$ & 4 & - & & $30-90^{\circ}$ & 6 & - \\
\hline & & $>30^{\circ}$ & 11 & - & & $>90^{\circ}$ & 13 & - \\
\hline & Medial & $0-30^{\circ}$ & 1 & - & Lateral & $0-10^{\circ}$ & 1 & - \\
\hline & rotation & $30-90^{\circ}$ & 4 & - & rotation & $10-30^{\circ}$ & 5 & - \\
\hline & & $>90^{\circ}$ & 10 & - & & $>30^{\circ}$ & 10 & - \\
\hline \multirow[t]{6}{*}{$\overline{\text { Neck }}$} & Flexion & $0-20^{\circ}$ & 1 & - & Extension & $0-30^{\circ}$ & 1 & - \\
\hline & & $20-45^{\circ}$ & 5 & - & & $30-60^{\circ}$ & 9 & - \\
\hline & & $>45^{\circ}$ & 8 & - & & $>60^{\circ}$ & 15 & - \\
\hline & Lateral & $0-30^{\circ}$ & 1 & - & Rotation & $0-30^{\circ}$ & 1 & - \\
\hline & bending & $30-45^{\circ}$ & 5 & - & & $30-60^{\circ}$ & 4 & - \\
\hline & & $>45^{\circ}$ & 13 & - & & $>60^{\circ}$ & 11 & - \\
\hline \multirow[t]{7}{*}{ Back } & Flexion & $0-20^{\circ}$ & 1 & - & Extension & Not incl & & \\
\hline & & $20-60^{\circ}$ & 6 & - & & & & \\
\hline & & $>60^{\circ}$ & 13 & & & & & \\
\hline & Lateral & $0-10^{\circ}$ & 1 & - & Rotation & $0-20^{\circ}$ & 1 & - \\
\hline & bending & $10-20^{\circ}$ & 5 & - & & $20-30^{\circ}$ & 3 & - \\
\hline & & $20-30^{\circ}$ & 12 & - & & $30-45^{\circ}$ & 7 & - \\
\hline & & $>30^{\circ}$ & 16 & - & & $>45^{\circ}$ & 14 & - \\
\hline
\end{tabular}

\section{Occupational Repetitive Actions}

OCRA is a synthetic index describing risk factors related to repetitive actions at work. The total number of technical actions performed during the shift is divided by the total number of recommended technical actions. The latter is counted from observed actions multiplied by weights given for the following factors: muscle force, posture of the parts of the upper limb, lack of recovery periods, daily duration of the repetitive work, and other additional factors. The ocra system comprise three assessment tools: 1) The ocra mini-checklist, which is a simplified version, as a preliminary screening tool is intended for special sectors (e.g. craftwork, small business, agriculture, etc.) in which the work is not organized according to precisely defined rates, times and cycles as it is in industry, 2) the ocra checklist for initial risk assessment, and 3) the OCRA index for precise and analytical risk assessment (30). 


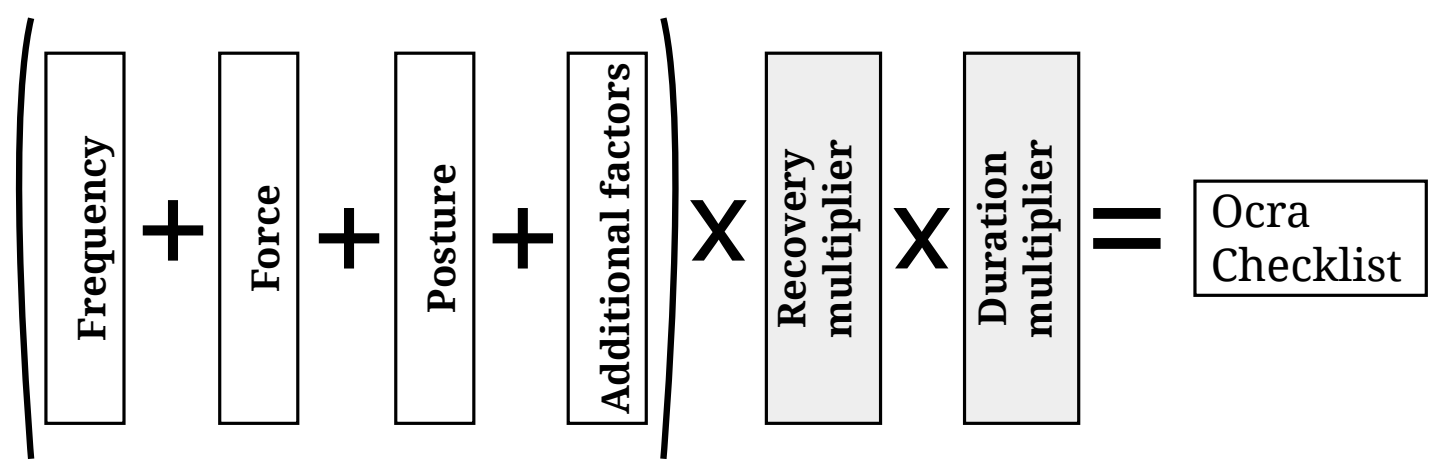

The calculation procedure for the OCRA Checklist.

\section{OWAS - the Ovako Working Posture Analysis System}

In the owas method the four most common work postures for the back, three postures for the arms and seven postures for the legs are identified, together with the load handled (three categories), these 252 options are then classified into four action categories (31). A portable system for coding and analyzing is currently available.

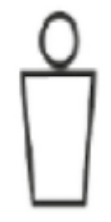

1

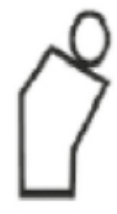

2

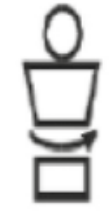

3

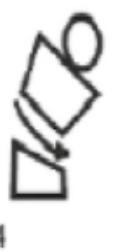

4
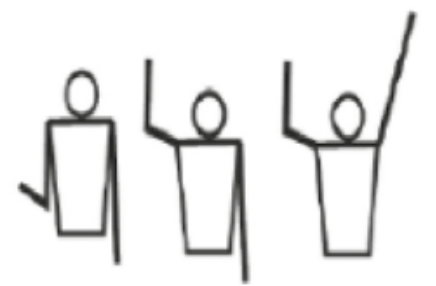

3

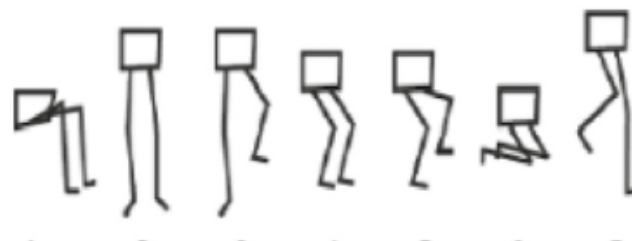

12

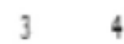

45

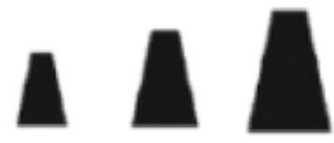
23 3

\begin{tabular}{|c|c|c|c|}
\hline $\begin{array}{c}\text { back posture } \\
\text { code }\end{array}$ & $\begin{array}{c}\text { forearms } \\
\text { position code }\end{array}$ & $\begin{array}{c}\text { legs work } \\
\text { code }\end{array}$ & $\begin{array}{c}\text { expternal load } \\
\text { volume code }\end{array}$ \\
\hline
\end{tabular}




\section{Posture, Activity, Tools, and Handling - PATH}

РАтH has a work sampling-based approach, it was developed specifically to characterize the ergonomic hazards of heavy highway construction work. PAтH is based on the owAs definitions and uses the same risk levels [32].

TRUNK
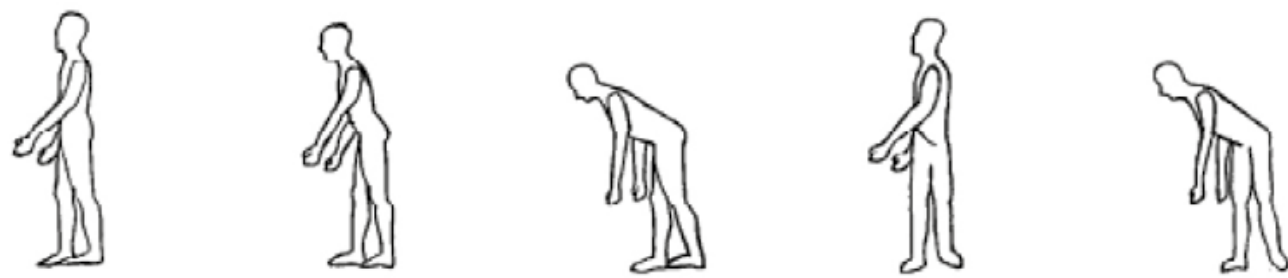

(1) Neutrai Moderate Forward Fiox
$20^{\circ}<$ Flexion $<45^{\circ}$ Severe Forward
Flexion $>45^{\circ}$ (3) Lateral Bending or Twisting Forward Flexion $<20^{\circ}$ and

(4) Flexion and Twisting and Twisting $<20^{\circ}$

Forward Flexion and Twisting $>20^{\circ}$

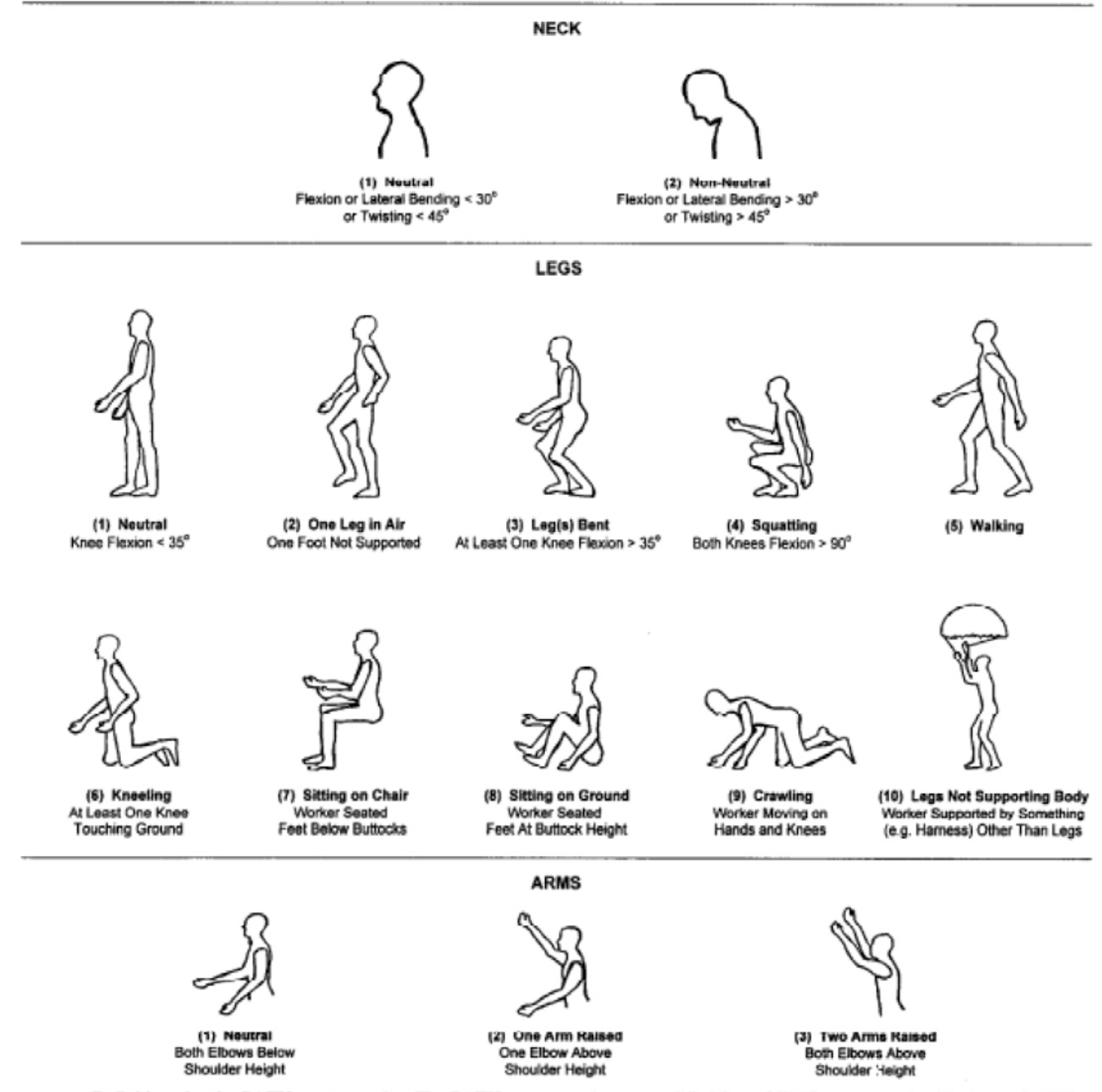

Definitions for the PATH posture codes. The PATH posture codes are modified from OWAS posture codes (Karhu et al, 1977) 


\section{PLIBEL}

PLIBEL is a method for the identification of musculoskeletal stress factors which may have injurious effects. The checklist is designed so that items, ordinarily checked in a workplace assessment of ergonomic hazards, can be listed and linked to symbols of five body regions. The list of items consists of questions concerning awkward work postures, tiresome work movements, poor design of tools or workplace, and stressful environmental or organizational conditions. For a PLIBEL registration there is no duration criterion, excluding rare events or peak loads (33).

Method for the identification of musculo-skeletal stress factors which may have injurious effects-PLIBEL

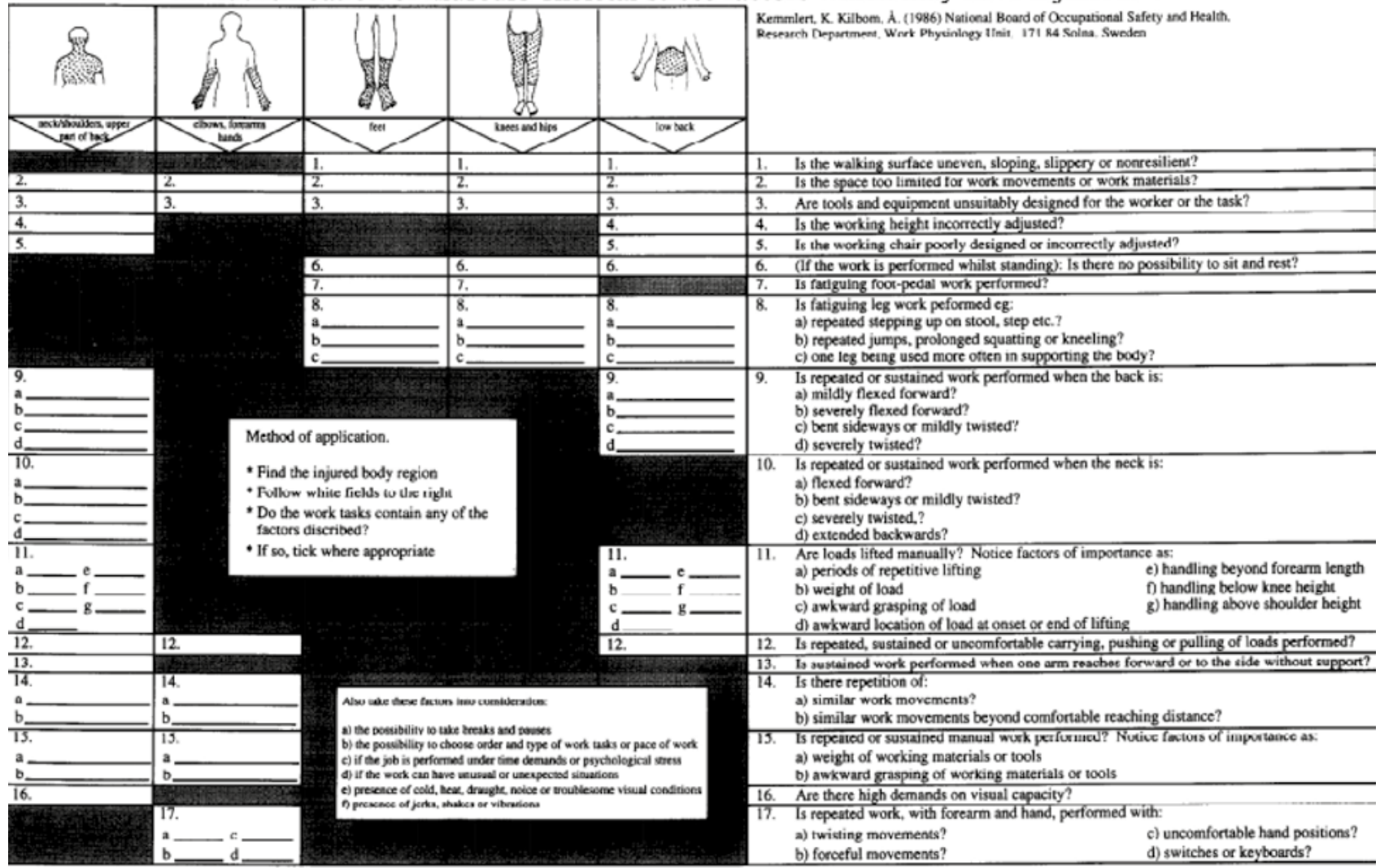

Source: https://www.sciencedirect.com/science/article/pii/0003687095000225?via\%3Dihub

\section{Quick Exposure Check - QEC}

QEC is suitable for the assessment of many different types of work and work tasks, but each task should be assessed separately. The starting point for the assessment is the worst possible work positions for each body part involved in a task. The observer assesses body posture and body movements while the employee (in cooperation with the observer) estimates time, level of force, visual requirements, vehicle driving, vibrating tools, work load and stress levels. Different combinations of these parameters give points that sum up one body part at the time. Priority levels for possible interventions are proposed for the endpoints (34). 

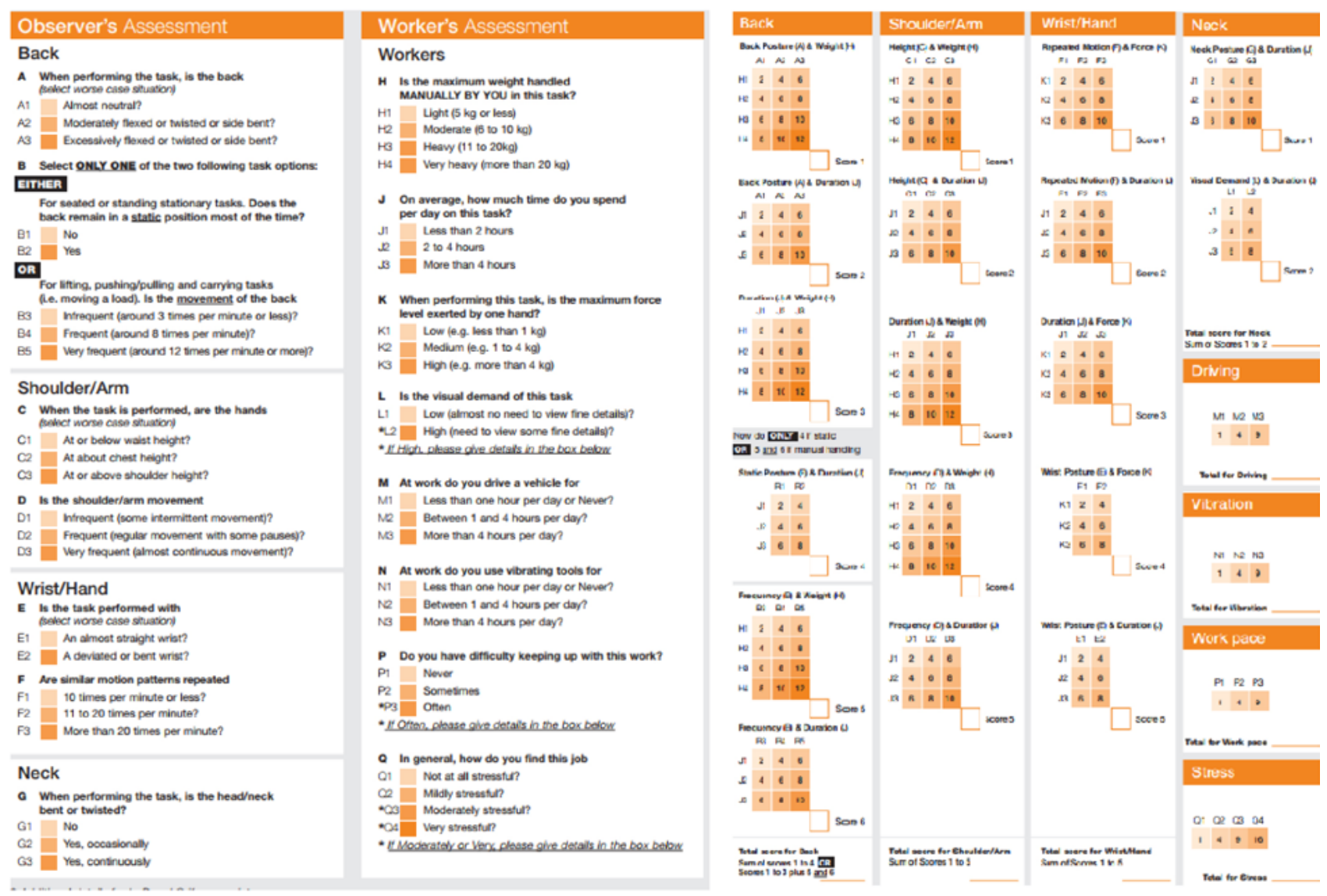

Source: http://www.hse.gov.uk/research/rrpdf/rr211.pdf

\section{Risk Management Assessment Tool for Manual Handling Proactively - RAMP}

RAMP is a newly developed tool to support the assessment and management of risks of musculoskeletal disorder (MSD) in manual handling work. It consists of four modules: 1) a checklist-based “RAMP I” for screening of MSD risks (yes/no), 2) a “RAMP II” which enables a more in depth analysis, 3) a "Results module" for presenting, visualizing and communicating the results, and 4) an "Action module”, for the development of risk reducing measures and systematic risk management. RAMP uses a number of equations in which multiplicative interaction of different ergonomic factors are taken into account. The tool includes two types of assessments, the worst case and the average case, intended to cover both cumulative load and peak load. Both, the initial and the sustained force can be assessed (35). 
The RAMP-tool

\begin{tabular}{|c|}
\hline RAMP I - Checklist \\
\hline Identification of risk factors
\end{tabular}$\longrightarrow$ RAMP II - Assessment

Fuente: https://www.ramp.proj.kth.se/

\section{Rapid Entire Body Assessment Method - REBA}

This ergonomic assessment tool uses a systematic process to evaluate the whole body postural MSD and risks associated with work tasks. A single page worksheet is used to evaluate required or selected body posture, forceful exertions, type of movement or action, repetition, and coupling (36).

ERGONEMICS REBA Employee Assessment Worksheet Tosk Name: Dote:

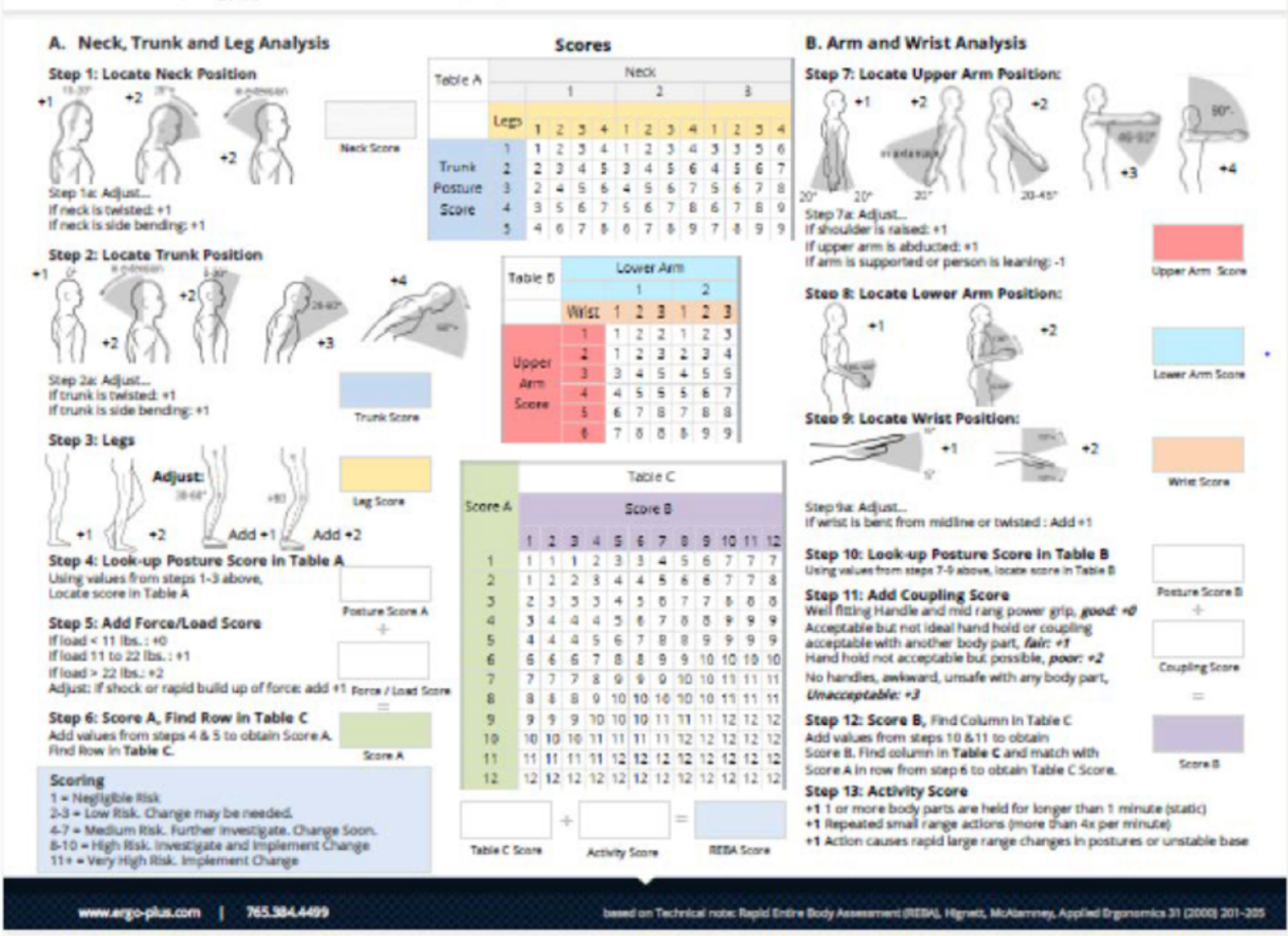

Source: Hignett, S. and McAtamney, L., Rapid Entire Body Assessment(REBA), Applied Ergonomics, 31, 201-205, 2000. 


\section{Rapid Upper Limb Assessment Method - RULA}

A single page worksheet is used to evaluate required body posture, force, and repetition. Based on the evaluations, scores are entered for each body region in section A) for the arm and wrist, and section B) for the neck and trunk. After the data for each region is collected and scored, tables on the form are then used to compile the risk factor variables, generating a single score that represents the level of MSD risk. The RuLA was designed for easy use without the need for advanced ergonomic knowledge or expensive equipment. By using the RULA worksheet, an evaluator will assign a score for each of the following body regions: upper arm, lower arm, wrist, neck, trunk, and legs. After the data for each region is collected and scored, tables on the form are used to compile the risk factor variables, generating a single score that represents the level of MSD risk (37).

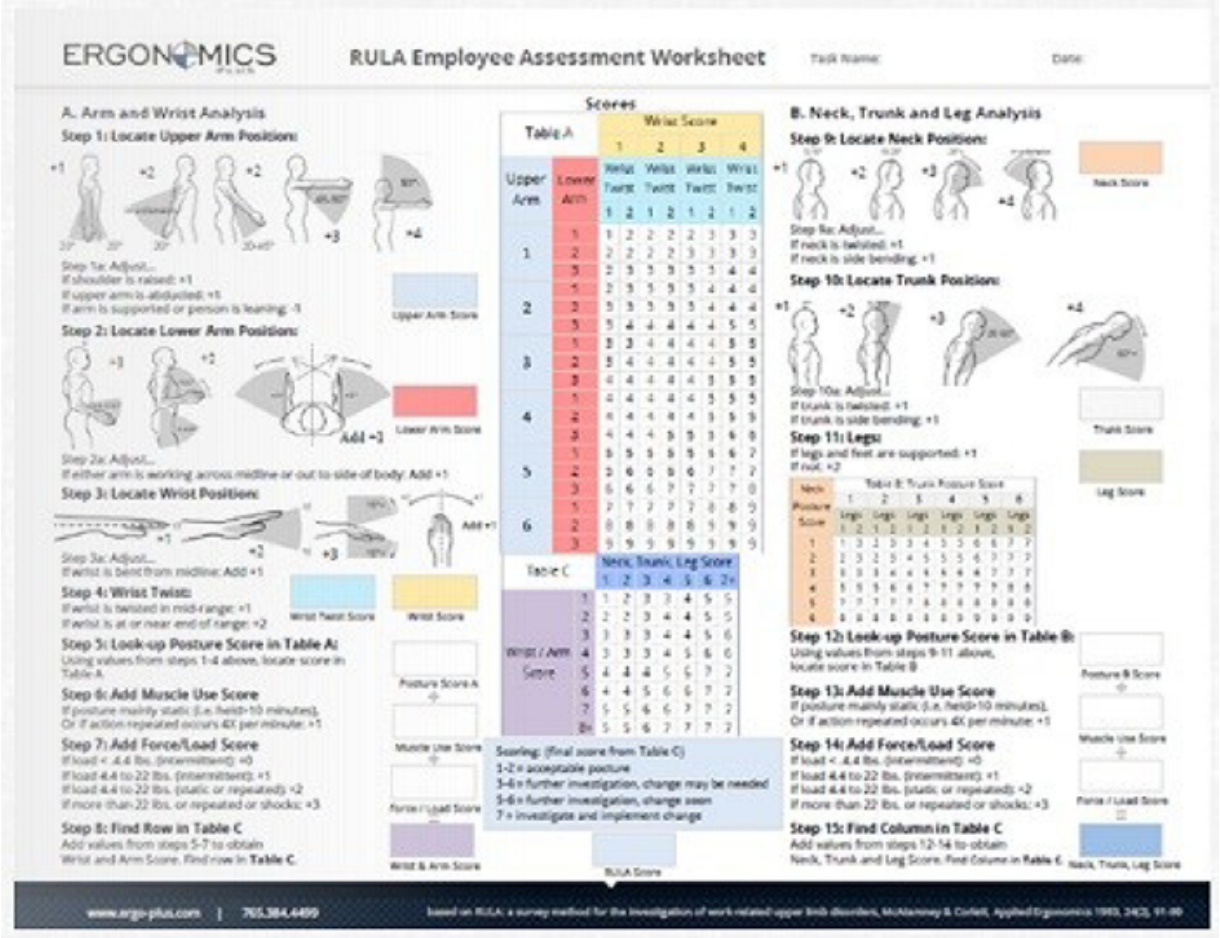

Source: http://ergo-plus.com/rula-assessment-tool-guide/

\section{Strain Index - SI}

The methodology involves the measurement or estimation of six task variables (intensity of exertion, duration of exertion per cycle, efforts per minute, wrist posture, speed of exertion, and duration of task per day), the assignment of an ordinal rating for each variable according to exposure data, and then the assignment of a multiplier value for each variable. The strain index is the product of these six multipliers (38). 
Observational Methods for Assessing Ergonomic Risks for Work-Related Musculoskeletal Disorders

TABLE I. Rating Criteria

\begin{tabular}{clccccc}
\hline Rating & $\begin{array}{c}\text { Intensity of } \\
\text { Exertion }\end{array}$ & $\begin{array}{c}\text { Duration of Exertion } \\
\text { (\% of cycle) }\end{array}$ & Efforts/Minute & $\begin{array}{c}\text { Hand/Wrist } \\
\text { Posture }\end{array}$ & $\begin{array}{c}\text { Speed of } \\
\text { Work }\end{array}$ & $\begin{array}{c}\text { Duration per } \\
\text { Day (hrs) }\end{array}$ \\
\hline 1 & light & $<10$ & $<4$ & very good & very slow & $\leq 1$ \\
\hline 2 & somewhat hard & $10-29$ & $4-8$ & good & slow & $1-2$ \\
\hline 3 & hard & $30-49$ & $9-14$ & fair & fair & $2-4$ \\
\hline 4 & very hard & $50-79$ & $15-19$ & bad & fast & $4-8$ \\
\hline 5 & near maximal & $\geq 80$ & $\geq 20$ & very bad & very fast & $\geq 8$ \\
\hline
\end{tabular}

TABLE II. Rating Criteria

\begin{tabular}{ccccccc}
\hline Rating & $\begin{array}{c}\text { Intensity of } \\
\text { Exertion }\end{array}$ & $\begin{array}{c}\text { Duration of Exertion } \\
\text { (\% of cycle) }\end{array}$ & Efforts/Minute & $\begin{array}{c}\text { Hand/Wrist } \\
\text { Posture }\end{array}$ & $\begin{array}{c}\text { Speed of } \\
\text { Work }\end{array}$ & $\begin{array}{c}\text { Duration per } \\
\text { Day (hrs) }\end{array}$ \\
\hline 1 & 1 & 0.5 & 0.5 & 1.0 & 1.0 & 0.25 \\
\hline 2 & 3 & 1.0 & 1.0 & 1.0 & 1.0 & 0.50 \\
\hline 3 & 6 & 1.5 & 1.5 & 1.5 & 1.0 & 0.75 \\
\hline 4 & 9 & 2.0 & 2.0 & 2.0 & 1.5 & 1.00 \\
\hline 5 & 13 & $3.0^{\mathrm{A}}$ & 3.0 & 3.0 & 2.0 & 1.50 \\
\hline
\end{tabular}

$\%$ Duration of Exertion $=100 * \frac{\text { (Average Duration of Exertion per Cycle) }}{\text { (Average Exertional Cycle Time) }}$

A If duration of exertion is $100 \%$, then efforts/minute multiplier should be set to 3.0

Source: https://ergoweb.com/the-strain-index-job-analysis-method-q-a/ https://www.ergocenter.ncsu.edu/wp-content/uploads/ sites/18/2018/01/Ecnc-Revised-Strain-Index-Calculator.pdf 


\section{Workplace Ergonomic Risk Assessment - WERA}

WERA provides a quick method for screening the working task for assessing the physical risk factors associated with wRMSDS. The wERA tool covers six physical risk factors including posture, repetition, force, vibration, contact stress and task duration and it involves the five main body regions: shoulder, wrist, back, neck and leg. It has a scoring system and contains action levels, which provide a guide to the level of risk and the possible need for action to conduct more detailed assessments (39).

\section{Workplace Ergonomic Risk Assessment (WERA)}

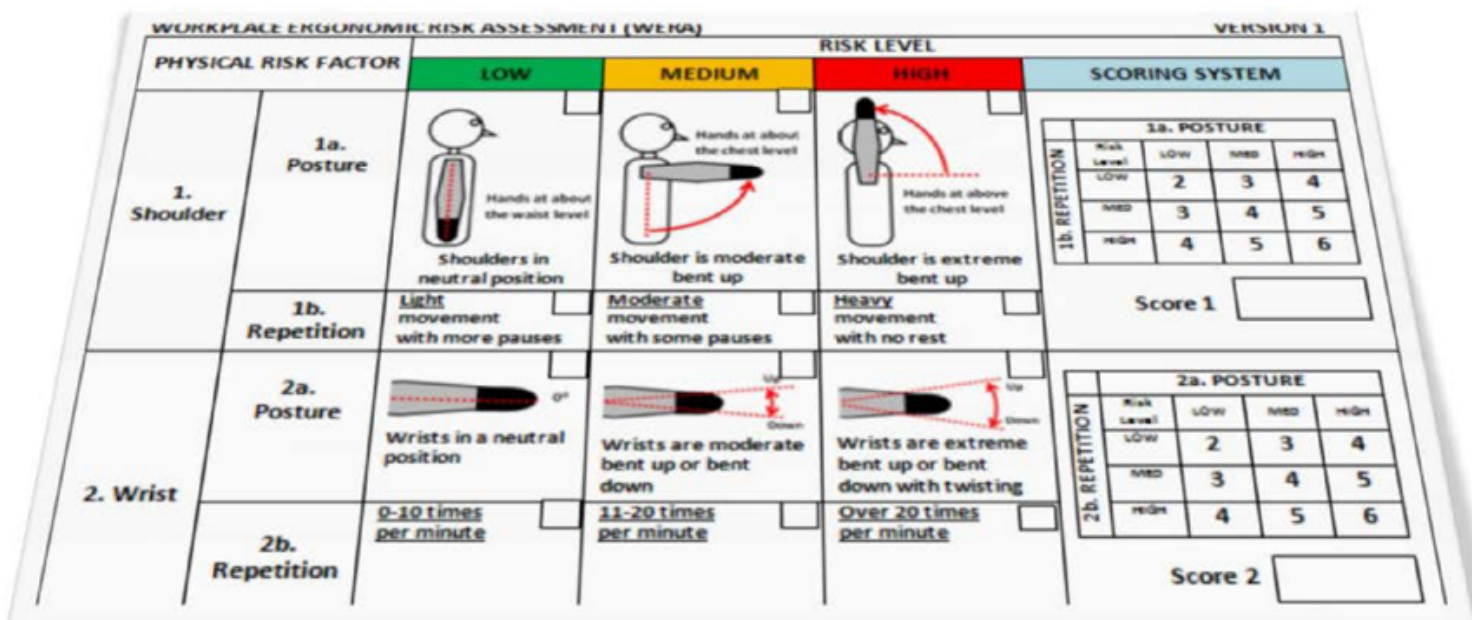

